\title{
THE ROLE OF FORCE OR POWER IN LIEBIG'S PHYSIOLOGICAL CHEMISTRY
}

\author{
by \\ VANCE M. D. HALL*
}

I

IN THE last two decades historians of science have shown increasing interest in the emergence of the doctrine of the conservation of energy. A particular aspect of this topic has been the contribution made to nineteenth-century discussions on force and power by men working in physiology: Hermann Helmholtz (1821-1894) and Julius Robert Mayer (1814-1878) are probably the best known. The seminal paper for this topic among historians of science was T. S. Kuhn's 'Energy conservation as an example of simultaneous discovery', 1 in which Kuhn identified about a dozen natural philosophers in Europe who, largely independent of one another, were developing views on forces and their interrelations which resembled and probably led up to the formal principles of the correlation of forces (as enunciated especially by William Robert Grove $(1811-1896)^{2}$ ) and the conservation of energy (as enunciated by Hermann Helmholtz in 18473). Of those dozen natural philosophers, Kuhn identified three who were working in physiology - Helmholtz, Mayer, and Liebig (1803-1873). ${ }^{4}$

This paper will examine Liebig's ideas on force or power in the light of Kuhn's and later scholars' studies. However, I wish to make three preliminary comments before examining Liebig's work in detail.

First, although some scholars have discussed Liebig's interest in dynamics since Kuhn's paper and in greater detail than he did, they have usually addressed themselves

\footnotetext{
* Vance M. D. Hall, B.A., D.I.C., M.Sc., Ph.D., Department of History of Science, The Open University, Walton Hall, Milton Keynes, Bucks. MK7.

1 T. S. Kuhn, 'Energy conservation as an example of simultaneous discovery', in Marshall Clagett (editor), Critical problems in the history of science, Madison, University of Wisconsin Press, 1959, pp. 321356.

2 W. R. Grove, On the correlation of physical forces, London, S. Highley, 1846. Grove's role in the debate on force and energy is discussed quite fully by Kuhn, ibid., and by P. M. Heimann, 'Conversion of forces and the conservation of energy', Centaurus, 1973-74, 18: 147-161.

${ }^{3}$ H. Helmholtz, 'Ueber die Erhaltung der Kraft', translated in Russell Kahl (editor), Selected writings of Hermann von Helmholtz, Connecticut, Wesleyan University Press, 1971, pp. 3-55. Helmholtz's work on force and energy has been discussed by a number of scholars. However, it has rarely been discussed fully within a physiological context, an omission which is serious since Helmholtz was a physiologist at the time he wrote his paper. I have tried to redress the balance in my unpublished Ph.D. thesis, 'Some contributions of medical theory to the discovery of the conservation of energy principle during the late eighteenth and early nineteenth centuries', University of London thesis, 1977.

${ }^{4}$ Kuhn, op. cit., note 1 above. A fourth physiologist, whom Kuhn mentioned rather tentatively, was Peter Mark Roget (1779-1869).
} 


\section{The role of force or power in Liebig's physiological chemistry}

to different issues than those on which I shall focus 5 and they have sometimes neglected important parts of his writings on the chemistry of living organisms. I shall argue, in particular, that hitherto there has been inadequate appreciation of his treatise on Organic chemistry in its applications to agriculture and physiology $y^{6}(1840)$. Indeed, few Liebig scholars, except those who have been directly interested in his influence in agriculture, have taken seriously Holmes' assessment of that treatise, that "Although he was concerned primarily with plants and their cultivation, Liebig revealed here some of the general approaches to Chemistry in its relation to physiology which he later applied to animal chemistry. He made statements even stronger than those in Animal chemistry about the neglect of chemistry by physiologists, and expressed conceptions of the relation of vital to chemical forces which foreshadow those of the later book."7

Second, in addition to neglecting Liebig's Agricultural chemistry some scholars have neglected or at least minimized his interest in force. One scholar in particular has relegated this aspect of Liebig's natural philosophy almost to insignificance, as a result of which one must question seriously his interpretation of Liebig's metaphysics of science. 8

Third, although this paper arises from work that I began and largely completed several years ago, I would like it to be considered within the perspective of a discussionpaper recently presented by Dr. W. H. Brock at a conference on 'Problems and

5 The principal studies in which Liebig's dynamics have been examined are as follows: (i) Kuhn, op. cit., note 1 above. (ii) J. G. Goodfield, The growth of scientific physiology, London, Hutchinson, 1960. (iii) E. Mendelsohn, Heat and life, Cambridge, Mass., Harvard University Press, 1964. (iv) F. L. Holmes' Introduction to the latest English reprint of Justus Liebig, Animal chemistry, or organic chemistry in its application to physiology and pathology, New York, Johnson Reprint Corporation, 1964. (v) T. O. Lipman, 'The response to Liebig's vitalism', Bull. Hist. Med, 1966, 40: 511-524. (vi) T. O. Lipman, 'Vitalism and reductionism in Liebig's physiological thought', Isis, 1967, 58: 167-185. (vii) T. S. Hall, Ideas of life and matter. Studies in the history of general physiology, 600 B.C.-A.D. 1900, vol. 2, Chicago, University of Chicago Press, 1969. (viii) Y. Elkana, The discovery of the conservation of energy, London, Hutchinson Educational, 1974, particularly chapter IV, 'Physiological background'. (ix) E. Glas, 'The Liebig-Mulder controversy', Janus, 1976, 63: 27-46. (x) Idem, 'An unnoticed explanation of enzyme action: the view of G. J. Mulder (1843)', ibid., 275-288. (xi) Idem, 'Methodology and the emergence of physiological chemistry', Stud Hist. Phil. Sci. 1978, 9 (No. 4); 291-312.

6 J. Liebig, Die Chemie in ihrer Anwendung auf Agrikultur und Physiologie, Braunschweig, F. Vieweg, 1840. All references in this paper will be to the first English edition, Organic chemistry in its applications to agriculture and physiology, edited from the manuscript of the author by Lyon Playfair, London, Taylor \& Walton, 1840.

7 Holmes, op. cit., note 5 above, p. XXI.

8 Despite some useful aspects of his three papers on Liebig and Mulder, op. cit., note 5 above, Eduard Glas has ignored much of the excellent secondary literature on Liebig. Perhaps this has been due to his primary concern to approach Liebig as a philosopher of science, using the philosophy of science of Karl Popper, rather than as a historian. Indeed, the loopholes in Glas's papers seem to me to underline how critically the philosophy of science depends on a thorough history of science if it is to be accurate and useful to philosophers, historians, and scientists. The relative paucity of references to, and discussions of, studies by other Liebig scholars in Glas's papers suggests to me that his historical appreciation, particularly of Liebig's dynamics, is incomplete. Nowhere is this more apparent than in his evaluation of Liebig's vitalism and in his disagreement with Lipman, in his 1978 paper, op. cit., note 5 (xi) above, p. 303. I must also confess to finding some of Glas's more general comments somewhat bewildering. For instance, what does he mean by his assertion that "In the first decades of the nineteenth century vitalism prevailed on the basis of a romantic Naturphilosophie"? (p. 295 of his 1978 paper). If that means, as it implies, that the common basis of all vitalism at that time was Naturphilosophie, it is totally untrue. How could the vitalisms of Bichat, Broussais, Abernethy, and Lawrence be called dependent on Naturphilosophie? Moreover, as I shall argue in this paper, Liebig's vitalism owed nothing to it. 
perspectives in the history of chemistry' organized by The British Society for the History of Science ${ }^{9}$ Dr. Brock's paper, on 'Liebigiana: old and new perspectives', discussed the paradox that, despite Liebig's enormous prestige in his own lifetime, relatively little has been published about him since his death in 1873. Dr. Brock pointed out that "The Isis bibliography, for example, offers only 40 items (less than one per annum) between 1913 and 1965, compared with over 400 on Newton, 300 on Darwin, or (to compare like with like) 56 items for Berzelius and 95 for Faraday." 10 To this I might add that there are 158 items for Lavoisier and 42 for Davy. Dr. Brock asked, "why, if Liebig was so important historically, does he attract so little attention from both the German and English speaking historical communities?"11

I shall offer a tentative answer to that question at the end of this paper. Here, however, I wish only to endorse Dr. Brock's comments, especially the importance he attached to the vast quantities of Liebig correspondence "lying largely forgotten and unexploited" in the Gesellschaft Liebigs-Museum at Giessen and the Baeyerische Staatsbibliothek at Munich. I wish to address this paper to 'Liebigiana: old and new perspectives', hopefully adding to the new.

II

On opening Liebig's treatise on Animal Chemistry, or organic chemistry in its application to physiology and pathology (1842) it is difficult not to be struck by his preoccupation with Kraft - a word that could be translated mainly as "force" but also, though less commonly, as "energy" or "power". The various vital, chemical, and physico-mechanical forces were clearly central concepts in his natural philosophy, indeed so central that some passages in Animal chemistry where he discussed force were sometimes not far short of poetry. In both their epigrammatic form and their frequent flamboyance such passages remind one more of the writings of Goethe, Schelling, and the Naturphilosophen, whom Liebig denounced so heartily, than of the writing of modern chemistry. I cannot avoid the conclusion that force had fired his imagination as well as his science.

Kuhn asserted that Liebig's interest in forces, or rather in their interrelations, stemmed from his considering the duty of the electric motor, as a result of which he proposed that the chemical equivalents of the elements involved determine the work that is retrievable from chemical processes by electrical or thermal means. Kuhn wrote that: "Joule and Liebig reached energy-conservation by asking an old engineering question, 'What is the duty?' about the new conversion processes in the battery-driven electric motor." 12

This contention is supported by several places in Animal chemistry where Liebig discussed the force- or energy-conversions in electrochemical processes. However, since he also discussed other types of energy-conversions, such as the production of motion by heat in steam-engines and the relation of vital to chemical force there is no $a$

\footnotetext{
9 W. H. Brock, 'Liebigiana: old and new perspectives', Leicester, 6-8 April 1979. Dr. Brock's paper was not a formal one, but since it aroused some interest and is so useful, especially for its bibliography, I shall cite it here - of course with Dr. Brock's permission.

10 Ibid., p. 1.

11 Ibid., p. 1.

12 Kuhn, op. cit., note 1 above, p. 334.
} 


\section{The role of force or power in Liebig's physiological chemistry}

priori reason to assume that the duty of the electric motor was the foundation-stone of Liebig's ideas on energy-conservation. Besides, I am not aware of any discussion of the electric motor or of the processes exclusive to it in Liebig's Agricultural chemistry, and that book is as concerned with force as Animal chemistry is.

Some departure from Kuhn's contention can be found in F. L. Holmes' lengthy and valuable introductory essay to the latest English reprint of Animal chemistry. Holmes discussed Liebig's ideas on force much more within the context of his physiological interests:

"In his Animal chemistry Liebig expressed two types of views about physiology which crucially influenced the future development of the science. Concerning the nature of physical and chemical processes underlying physiological functions, he first stated certain general principles which would hold true no matter what specific reactions take place within the organism. Second, he outlined a comprehensive, if largely speculative, scheme of the specific metabolic processes which he believed occur in animals. The former have remained as a foundation of physiology and biochemistry; the latter did not endure in the form he gave it, but was nevertheless almost as significant historically, for its immediate appeal helped inspire the school of experimental investigators who developed the field of energy-metabolism. This school thrived when disproving Liebig's erroneous theories as well as when confirming his correct guesses." 13

Perhaps the most important physiological issue that Liebig took up (from Antoine Lavoisier (1743-1794), Armand Séguin (1765-1835), César Despretz (1792-1863), and Pierre Dulong (1785-1838)) was animal heat. He attempted to prove that an animal obtains its body-heat solely from chemical reactions occurring between its food and its respirational oxygen. Nutrition coupled with respiration were therefore to be regarded as the sole source of animal heat. As Holmes pointed out, Liebig's confident espousal of this idea was not based on any really convincing evidence but rested instead on his intuitive feeling that things must be so; and that feeling rested on his belief in a persistence and conservation of force throughout natural phenomena:

"It was on the basis of such an understanding, rather than through empirical biological information, that Liebig discounted such alleged sources of heat as nervous action and the friction in the circulatory system mentioned by Despretz. These actions, he saw, were themselves produced ultimately at the expense of chemical "force". His insistence that the sole source of "force" for animals is the chemical force obtained from their food was Liebig's most significant contribution to the future field of biological energetics, because it stimulated physiologists to hope that they could account for all the energy an animal expends producing heat or work, by carefully determining the types and quantities of compounds it eats." 14

So far, I concur with Holmes. Where we part company, however, concerns the basis

13 Holmes, op cit., note 5 above, p. XXXV.

14 Ibid., p. XLII-XLIII. 


\section{Vance M. D. Hall}

of Liebig's ideas on the indestructibility of force, for although Holmes did not explicitly support Kuhn's assertion of the electric-motor origin of Liebig's concept, he did not ground Liebig's concept firmly enough within physiology and physiological chemistry. For instance, he wrote that

"The view that in an animal the decomposition of a certain amount of tissuesubstance requires a certain amount of oxygen and produces a proportional amount of muscular work he compared to the action of a voltaic cell in which the reaction between a certain quantity of zinc and copper produces a proportional amount of mechanical, electrical or magnetic "force." When the conservation of energy was demonstrated more rigorously a few years later, Liebig's views were transformed with little alteration into an application of that principle to biological phenomena."15

The last sentence reveals Holmes' basic agreement with Kuhn. In my opinion they have grasped the wrong end of the stick, for I shall argue that Liebig's ideas on forces arose at least as much out of his physiological interests as out of a consideration of electrochemical processes, and that when the principle of Erhaltung der Kraft was put on a firmer footing in the late 1840s and 1850s Liebig's applications of it then to biological phenomena were but a reiteration of his earlier applications, such as can be found in his Agricultural chemistry, his Animal chemistry, and his Familiar letters on chemistry (first published 1843).

To appreciate the connexion between Agricultural chemistry and Animal chemistry, let us recall that they were Parts I and II of his report on the state of organic chemistry to the British Association for the Advancement of Science. ${ }^{16}$ As one might expect, therefore, they employed a common approach and a common set of fundamental ideas. One of their common ideas concerned the role of force in the vital economy.

Throughout the first part of Agricultural chemistry, entitled 'The chemical processes in the nutrition of vegetables', Liebig was concerned mainly with the transformation of inorganic into organic matter; this required force - not only chemical affinities, but also heat, light, electrical force, and motion. The interrelations of these forces could best be seen through their relations to the vital force. By vital force Liebig seems to have had in mind an explicans for several phenomena that were to be found only in living systems; precisely what its nature was he did not know, but he did believe that its relations with other dynamical agents (whose natures were also unknowable) might be discovered. This quest for dynamical relations was already conspicuous in his Agricultural chemistry and it became massively important in Animal chemistry. In the former he wrote: "We see, therefore, that this mysterious principle has many relations in common with chemical forces, and that the latter can indeed replace it. What these

15 Ibid., p. XLVI.

16 Liebig dedicated Animal chemistry to the British Association for the Advancement of Science. In his 'Dedication' he added that a third part of his Report would appear which would "contain an investigation of the food of man and animals" (p. XXIII). This appeared as Researches on the chemistry of food, London, Taylor \& Walton, 1847. So far as I am aware, historians of science do not mention that this was intended as Part III of his Report to the British Association. That this was its purport is implied in the author's Preface. 


\section{The role of force or power in Liebig's physiological chemistry}

relations are, it remains for physiologists to investigate." 17

Whatever such relations were, it seems that chemical force was the fundamental "motor" in Liebig's agricultural chemistry; for instance, in discussing plant metabolism he declared that: "Whatever we regard as the cause of these transformations, whether the Vital Principle, Increase of Temperature, Light, Galvanism, or any other influence, the act of transformation is a purely chemical process." 18

Hence the need to apply the insights of chemistry to physiology and agriculture. However, it must be stressed that the type of chemistry that Liebig wanted to apply to living phenomena was not merely that which dealt with the elementary compositions of the chemical inputs and outputs of organisms. Running throughout Agricultural chemistry was a dynamic type of chemistry ${ }^{19}$ which employed the words and ideas of physics as well as of chemistry. That was surely why on several occasions Liebig advocated the use of physics as well as chemistry in physiology: in Agricultural chemistry he lamented that " . . . in botany the talent and labour of enquirers has been wholly spent in the examination of form and structure: chemistry and physics have not been allowed to sit in council upon the explanation of the most simple processes." 20 Even more importantly, in Animal chemistry he employed an axiom straight from physics:

"The want of a just conception of force and effect, and of the connexion of natural phenomena has led chemists to attribute a part of the heat generated in the animal body to the action of the nervous system. If this view exclude chemical action . . . as a condition of nervous agency, it means nothing else than to derive the presence of motion, the manifestation of a force, from nothing. But no force, no power, can come of nothing." 21

In Agricultural chemistry there was no such explicit statement of the non-creation of force. However, that treatise appears much more meaningful and unified if one assumes some such underlying idea. Moreover, there is one passage where the question of the generation of force is raised; the force in question is vital force and Liebig is discussing its relation to external agents:

17 Liebig, op. cit., note 6 above, p. 58.

18 Ibid., p. 51.

19 In this I differ from E. Glas's analysis in his paper on 'An unnoticed explanation of enzyme action: the view of G. J. Mulder', op. cit., note $5(x)$ above. Although Glas rightly pointed out the importance of "communication of motion" in Liebig's chemistry, he has neglected the role of dynamics in Liebig's overall view of chemistry, especially in his chemistry of living organisms. Although Glas and I have not discussed the same work by Liebig, (Glas having focussed on Liebig's important paper 'Ueber die Erscheinungen der Gährung, Fäulniss und Verwesung und ihre Ursachen', Ann. Pharm., 1839, 30: 250-287), anyone who reads that paper will find the same ideas on fermentation, putrefaction, and decay in Agricultural chemistry which appeared a year later. However, since in his treatise he had an opportunity to develop his ideas and air his more theoretical ones, I think that the role of force comes across more clearly there than in the paper.

${ }^{20}$ Liebig, op. cit., note 6 above, p. 35.

21 Justus Liebig, Die Thierchemie oder organische Chemie in ihrer Anwendung auf Physiologie and Pathologie, Braunschweig, Friedrich Vieweg, 1842. Except when quoting passages in German, I shall refer to the more accessible 1964 reprint of the first English translation by William Gregory, namely Animal chemistry, or organic chemistry in its application to physiology and pathology,. . . with a new introduction by F. L. Holmes, New York, Johnson Reprint Corporation, 1964. This extract is from p. 28. 


\section{Vance M. D. Hall}

"The vital principle opposes to the continual action of the atmosphere, moisture and temperature upon the organism a resistance which is, in a certain degree, invincible. It is by the constant neutralization and renewal of these external influences that life and motion are maintained.

"The greatest wonder in the living organism is the fact that an unfathomable wisdom has made the cause of a continual decomposition or destruction, namely the support of the process of respiration, to be the means of renewing the organism and of resisting all the other atmospheric influences." 22

Thus, the living organism and the vital principle were seen to depend on external influences, namely the materials (such as carbon and oxygen) and the forces (the chemical affinities in food and oxygen) which came into the organism from without. It therefore seems that in Liebig's view the living organism could not generate its own force, just as it could not create its own matter. As if to leave no doubt about this point, Liebig devoted the penultimate paragraph of the treatise to it:

"After the removal of the cause which forced their union - that is after the extinction of life - most organic atoms retain their condition, form and nature only by a vis inertiae; for a great law of nature proves that matter does not possess the power of spontaneous action. A body in motion loses its motion only when a resistance is opposed to it; and a body at rest cannot be put in motion or any action whatever, without the operation of some exterior cause." 23

Actually, the clearest message on conservation in Agricultural chemistry was not the conservation of force or energy (Kraft) but the conservation of motion (Bewegung) or activity (Thätigkeit). This idea was specified only briefly in Agricultural chemistry, but it was expanded extraordinarily in Animal chemistry where it acquired several new names and was forged together with his concept of force. The discussion in the former occurred in the section 'On poisons, contagions and miasms', a topic in which Liebig's theories acquired considerable practical influence (as the work of Margaret Pelling has shown ${ }^{24}$ ). Liebig envisaged two types of poison: one type formed harmful chemical combinations with living tissue; the other type acted, not by means of chemical affinities, but by communicating its peculiar state of motion or activity to molecules in the organism. These latter poisons

“. . . are generated during certain processes of decomposition and . . . act on the animal economy as deadly poisons, not on account of their power of entering into combination with it, or by reason of their containing a poisonous material, but solely by virtue of their peculiar condition.

"In order to attain to a clear conception of the mode of action of these bodies, it is necessary to call to mind the cause on which we have shown the phenomena of fermentation, decay and putrefaction to depend.

"This cause may be expressed by the following law, long since proposed by Laplace and Berthollet, although its truth with respect to chemical phenomena has

22 Liebig, op cit., note 6 above, pp. 357-358.

23 Ibid., p. 383.

24 M. Pelling, Cholera, Fever and English medicine, 1825-1865, Oxford University Press, 1978. Much of this book, about a third, deals with Liebig's theory of disease and how it was taken up, and criticized, by British sanitarians. 
The role of force or power in Liebig's physiological chemistry

only lately been proved. 'A molecule set in motion by any power can impart its own motion to another molecule with which it may be in contact.'

"This is a law of dynamics, the operation of which is manifest in all cases in which the resistance (force, affinity or cohesion) opposed to the motion is not sufficient to overcome it." 25

This "law" enabled him to explain a number of important phenomena that other investigators had assigned to vitalistic causes; one such was alcoholic fermentation, whose explanations by Charles Cagniard-Latour (1777-1859), Friedrich Kützing (1807-1893), and Theodore Schwann (1810-1882) Liebig vehemently opposed.26

Before leaving his Agricultural chemistry it would be useful to summarize the view of vital force that Liebig presented in it. This is a difficult task for, as other Liebig scholars have pointed out, his exposition of this issue was inconsistent; throughout his life he seems to have felt his way precariously between the mechanistic and the living, between the phenomena that he and his contemporaries could cheerfully attribute to the physico-chemical forces in nature, and those phenomena whose uniqueness he felt bound to attribute to another type of force which he could only call vital. His vital force had at least two major functions in Agricultural chemistry:

(1) It regulated ordinary chemical forces in such a manner that characteristically vital phenomena, like reproduction, could occur. One might even say that the prime mover in all living organisms was seen as chemical force, and that the prime regulator or director of that force was vis vitae. In this function as a regulator of chemical force, Liebig's vital force strongly resembled the physical forces, for "The chemical forces are subordinate to this cause of life, just as they are to electricity, heat, mechanical motion, and friction. By the influence of the latter forces, they suffer changes in their direction, and increase or diminution of their intensity, or a complete cessation or reversal of their action. Such an influence and no other, is exercised by the vital principle over the chemical forces." 27

(2) The vital force was also responsible for the forms which seemed to characterize living systems. If we may use Aristotelian terms to make this clear, his vital force was essentially a "formal cause" rather than an "efficient cause"; and it is in the former sense that the word "cause" in the extract above should be understood. Hence he wrote: "Our notion of life involves something more than mere reproduction, namely the idea of an active power exercised by virtue of a definite form, and production and generation in a definite form. By chemical agency we can produce the constituents of muscular fibre, skin and hair; but we can form by their means no organized tissue, no organic cell." 28

Liebig was thus able sometimes to envisage the forces of physics and chemistry as the sole efficient causes or agents in living organisms even though he was, and remained always, a vitalist.

25 Liebig, op cit., note 6 above, pp. 343-344.

26 One of the most scholarly accounts of Liebig's theory of alcoholic fermentation and his criticisms of Cagniard-Latour, Kützing, Pasteur, Schwann, et al., is to be found in J. S. Fruton, Molecules and life. Historical essays on the interplay of chemistry and biology, New York, John Wiley, 1972, pp. 22-86.

27 Liebig, op. cit., note 6 above, p. 355.

28 Ibid., p. 354. 
This analysis of Liebig's Agricultural chemistry accords well with other scholars' analyses of his biological thought in general. For instance, Timothy Lipman in a paper ${ }^{29}$ which largely neglected the Agricultural chemistry and relied mostly on Animal chemistry and Familiar letters offered the following characterization of his ideas on living organisms: that a "successful" explanation had to be as reductionistic and chemical as possible, and that if this could be done nothing else was required; 30 that vital force was not a hindrance to experiment, but rather it was a concept which was reconcilable with scientific law; that just as science would never know the essence of the causes of light, electricity, or magnetism, because these were only mental categories, so too the physiologist would never know the essence of vital force; that nonetheless, since "the laws of these concepts could be known, because they were manifested in phenomena," these causes or forces had to exist; 31 and that his vital force was to be a force "with the same conceptual boundaries as any inorganic force." 32

\section{III}

Turning now to Liebig's Animal chemistry, it will be useful to bear in mind several themes when examining his physiological dynamics: the concept of force in general, and several force-derived concepts that were being developed; vital force, what it achieves and how it relates to other forces; the dynamical implications of respiration and nutrition; and the ontology of force. These themes should also be borne in mind in the topic that I shall discuss before examining the Animal chemistry, namely the physiology of Johannes Müller (1801-1858).

All historians of the life-sciences agree that Müller occupied an important place in the emergence of the new German physiology of the 1840s. Yet Müller's own work in physiology has not been studied to the extent it deserves; 33 and most of the historians who have discussed him have focused on his providing an unwitting springboard for the launching of the reductionist physiology of a brilliant handful of his students. Those students were Ernst Brücke (1819-1892), Emil DuBois-Reymond (1818-1896), Helmholtz, Schwann, and Rudolph Virchow (1821-1902). Important as Müller's role was as the mentor of this particular group of physiologists, I wish to discuss the background he provided for Liebig and particularly for the Animal chemistry, a task that Liebig scholars have not really attempted.

Müller was unquestionably the most influential and brilliant physiologist in Europe during the second quarter of the nineteenth century. He was also one of the most paradoxical figures, for he sat at the transition in German physiology from the heady speculative science of the Naturphilosophen to the experimental science that his pupils propagandized and developed so well. In the felicitous phrase of Everett Mendelsohn,

29 Lipman, op. cit., note 5 (vi) above, 'Vitalism and reductionism in Liebig's physiological thought'.

30 Ibid., p. 172.

31 Ibid., p. 176. This point was made in several places in Agricultural chemistry as well as in Animal chemistry; see Animal chemistry, op. cit., note 21 above, pp. 7-8.

32 Lipman, op. cit., note 5 above, p. 177.

33 This point is also made by Elkana, op. cit., note 5 above, p. 109. Like most historians who have given some attention to Müller, Elkana has examined him primarily as the mentor of Helmholtz and his fellow reductionists. Hence, his discussion of Liebig's contribution to the emergence of the conservation of energy, though useful, lacks the background of Müller's physiology as it related to Liebig's aims. 
he sat "almost at the eye of the storm" 34 in the reform movements which swept Europe and, for our purposes in particular, Germany in the 1840s. Müller himself had been a staunch adherent of Naturphilosophie, but in the 1830s he rejected it and fashioned a new, experimental physiology which determined the development of that subject in German-speaking laboratories during the rest of the century. Müller was also influential as an editor; he took over the ailing journal, Archiv für die Physiologie, infused new life into it, and with the new title of Archiv für Anatomie, Physiologie und wissenschaftliche Medizin he made it the most influential journal in medical sciences in Europe. Müller's literary influence was also due to his Handbuch der Physiologie des Menschen (vol. 1, 1835; vol 2, 1837) which went through several German editions and quickly became a standard text in other languages. ${ }^{35}$ In his Handbuch, (hereinafter called Human physiology), as elsewhere, Müller surveyed the whole field of physiology, discussed fairly and in detail the works of his predecessors and contemporaries, attempted to adjudicate on those issues which in his opinion would become the key problem-areas in the evolution of physiology, and propounded his own view of how these problem-areas would be best investigated. For the purpose of this paper the last two are especially important.

The problem-areas that Müller felt would be crucial in the new physiology were: the nature of the forces operating within and upon the living organism; the process whereby vitality or organic force must continually be replenished during an organism's life; the natures of nutrition and respiration; and the import of philosophy, particularly the philosophies of Benedict Spinoza (1632-1677) and Immanuel Kant (1724-1804). Subsuming Müller's discussion of these issues was a belief in the fundamentally dynamic character of nature in which the key terms were Energie and Kraft. Of course, this Weltanschauung was not original, for Müller had been exposed to a powerful dose of Naturphilosophie during his medical studies at Bonn; 36 and since a dynamical worldview was one of the fundamental and most bewitching of the tenets of that movement it is not surprising that Müller was impressed with it. However, Müller went well beyond his Naturphilosophische mentors in striving to make his ideas on force more rigorous and more amenable to experimental investigation in chemistry, physics, and physiology. Nowhere was this striving more conspicuous than in his Human physiology.

In what follows, I shall describe some of the physiological issues to which Müller attempted to apply his dynamical ideas. As in the case of Liebig, however, we must be aware of the strict untranslatableness of such terms as Energie, Kraft, Naturkraft,

34 E. Mendelsohn, 'Revolution and reduction: the sociology of methodological and philosophical concerns in nineteenth century biology', in Y. Elkana (editor), The interaction between science and philosophy, Atlantic Highlands, New Jersey, Humanities Press, 1974, pp. 407-426. This quotation is from $\mathrm{p}$. 419.

35 J. Müller, Handbuch der Physiologie des Menschen, Coblenz, J. Hölscher Verlag, vol. 1, 1835, vol. 2 1837. Except when quoting an extract in German, I shall cite the English translation by W. Baly, Elements of physiology, London, Taylor \& Walton, 1838.

36 One of the best accounts of Müller's philosophical background is by M. Müller, 'Ueber die philosophischen Anschauungen des Naturforsches Johannes Müller', Arch. Gesch. Med. 1926, 18: 130-150, 209-234, 328-350. A briefer account is by J. Steudel, 'Johannes Peter Müller', in C. G. Gillispie (editor), Dictionary of scientific biography, New York, Charles Scribner's Sons, 1974, vol. 9, pp. 567-574. For a lengthier account of Müller's thought, see G. Koller, Des Leben des Biologen Johannes Müller, Stuttgart, Wissenschaftliche Verlagsgesellschaft, 1958. 
geistige/organische Wirken, etc. ${ }^{37}$

In volume I of Human physiology Müller discussed the physiology of nerves. There he set a challenge for physiologists, a challenge so explicit that its impact on his students and readers can scarcely be doubted; indeed, we know how soon it was to be taken up by his students. The issue was animal excitability:

"Physiologists have not, however, merely to ascertain the laws governing this general property, which unfortunately was the sole object which occupied the attention of [John] Brown and his followers; but to investigate the peculiar forces themselves which are susceptible of this excitation, and in this there is a great field opened for experimental science. In enquiring into the nature of the forces resident in the nerves, it is necessary to study the action of all kinds of stimuli upon them - a method of enquiry which acquires for physiology an experimental certainty similar to that which the sciences of physics and chemistry in reference to inorganic bodies enjoy. In chemical processes, reagents give rise only to products, combinations and decompositions; applied to organic bodies and especially to the nerves, their effects, however various they may be, are never other than manifestations of the proper forces of the bodies acted on, or modifications of their forces. It will be seen that all influences acting on the nerves either excite them or produce an altered state of their excitability; . . . the most different causes produce the same effect, because that on which they act possess but one kind of excitable force, and because agents in themselves the most different act here by virtue of the same quality, that of stimuli." 38

Already this area had been investigated in some detail; for instance, Müller was able to cite and praise the studies done on the physiological effects of galvanic stimuli by Luigi Galvani (1737-1798), Alexander von Humboldt (1769-1859), the English physiologist Richard Fowler ${ }^{39}$ (1765-1863), Johann Ritter (1776-1810), the young Czech physiologist Jan Purkyně40 (1787-1869) and Alessandro Volta (1745-1827).

37 The difficulty of translating a number of the German words that were used by those who were developing a dynamical type of science has been discussed by Kuhn, Goodfield, Elkana, Lipman, and a few others. The only substantial discussion of Müller's terminology, of which I am aware, is by W. Riese and G. E. Arrington, 'The history of Joharines Müller's doctrine of the specific energies of the senses: orginal and later versions', Bull. Hist. Med. 1963, 37: 179-183.

38 Op. cit., note 35 above, pp. 612-613.

39 Dr. Richard Fowler had written an account of experiments he had done as a young physician on the effects of galvanic stimuli on living organisms. His little book became highly respected and widely cited among English and German physiologists; it was also translated into several languages. The original edition was Experiments and observations relative to the influence lately discovered by $M$. Galvani, and commonly called animal electricity, Edinburgh, T. Duncan and others, 1793. Although Müller cited this English edition, it is much more likely that he had read a slightly later German version by A. Monro and R. Fowler, Abhandlungen über thierische Electricität und ihren Einfluss auf das Nervensystem, Leipzig, Weygandsche Buchhandlung, 1796. For a discussion of Fowler's ideas on forces, see my Ph.D. thesis, op cit., note 3 above, pp. 302-308 and the chapter on William Benjamin Carpenter (1813-1885), especially p. 259. I have also mentioned him in a paper on 'The contribution of the physiologist, William Benjamin Carpenter (18131885), to the development of the principles of the correlation of forces and the conservation of energy', Med. Hist., 1979, 23: 129-155.

40 Jan Evangelista Purkyně published a number of studies on galvanic effects, mostly connected with his study of the physiology of vision. Indeed, he was one of the key physiologists in Germany, and especially in his native Czechoslovakia, during the first half of the nineteenth century, and there were considerable 


\section{The role of force or power in Liebig's physiological chemistry}

Müller's own explanation of these galvanic studies was wholly physical and his Energie seemed not to have any metaphysical or Naturphilosophische character worth mentioning; his central idea was that the activities of nerves always entail expenditure of force or power which has to be replenished continually from external sources, especially by nutrition; nutrition was therefore seen as a dynamical process (i.e. as supplying the organism with Energie) as well as a material process (i.e. as supplying foodstuffs). Thus,

"All stimuli, which by producing changes in the matter of nerves excite reaction of them, are also capable of modifying their state of excitability. Reaction is always attended with an expenditure of power; it is the result of the material change; and the longer the excitement is continued, the greater is the change produced. . . . The daily changes in the system, consequent on the action of stimuli, are counterbalanced by the processes of nutrition." 41

In volume II of the Handbuch, which appeared two years after volume I, Müller extended this dynamical approach to all vital activities, again emphasizing that such activities entail changes on two levels: (i) changes in the chemical composition of tissues; and (ii) diminution of force or power in those active tissues. This idea of two levels of change in the living organism - chemical and dynamical - became a key character of Liebig's explanation of the organism, although Liebig did not admit any debt to Müller. The idea also influenced Müller's pupil, Helmholtz, for one of his earliest and most important experiments was designed to test the hypothesis that the expenditure of force in the living organism always entails chemical change: that was the point of his research on the excitation of excised frog's leg-muscles in 1845.42

Müller's own account of his dynamical physiology can be seen in the following description of nutrition:

"This constant reanimation of the tissues by the general vital stimuli ordinarily renders them capable of a proportionate exercise of their functions; but if their action is increased and accelerated, subsequent rest is necessary to restore as much power for new action as has been thus consumed. Generally, in the healthy state, just as much power is generated in a certain space of time as has been exhausted by the exercise of the functions; but there are cases in which the nutrition of the organ becomes gradually increased, while the state of action is either equal or regular, or

similarities and interaction between his experimental work and Müller's. Despite Purkyně’s importance, however, he has been largely ignored by English-speaking historians of science. I am indebted to my former teacher, Mikulăs Teich, for drawing my attention to him. There are a few studies on Purkyně available in English, of which the following are the most useful: (i) Jan Evangelista Purkyně, Prague, State Medical Publishing House, 1962, which contains two essays, one by V. Kruta, 'J. E. Purkyně - a creative scientist', and the other by M. Teich, 'The world outlook of Jan Evangelista Purkyně.' (ii) V. Kruta, The poet and the scientist. Johann Wolfgang Goethe. Jan Evangelista Purkyně, Prague, Academia, 1968. (iii) V. Kruta (editor), Jan Evangelista Purkyné (1787-1869). Centenary symposium, Brno, Universita Jana Evangelisty Purkyně, 1971.

41 Op. cit., note 35 above, p. 624.

42 H. Helmholtz, 'Ueber den Stoffverbrauch bei der Muskelaktion', Arch. Anat. Physiol. Wissenschaft. Med. 1845. A more accessible source is Helmholtz, Wissenschaftliche Abhandlungen, Leipzig, J. A. Barth, 1883, vol. II, pp. 735-744. For a brief discussion of this research, see Holmes, op cit., note 5 above, pp. LXXIII-LXXIV. 
alternates with rest. This is the case in youth . . . ."43

For Müller, the only true vital stimuli were heat, air, food, and water; these alone enabled life to become manifest and vital force to be replenished.44

From such passages one gets the impression that one of Müller's aims was to argue against the living organism as a creator of its own power, against its being a perpetuum mobile. ${ }^{45}$ Actually, this became explicit in his discussion of the nature of the organic or vital force: he sometimes gave the impression that "vital force" was only a heuristic phrase; yet whatever its nature he was certain that force in the living organism was never sui generis but always required replenishment from external sources of force. Between inorganic and organic forces he saw a fundamental correlation and interchangeability; to suppose the contrary, namely that organic force might be created by life itself, struck him as absurd. Hence he wrote that

"... the source of the increase of the organic or vital force seems, therefore, also to lie in the organization of new matter; and this being admitted, it must be allowed that plants, while they form new organic matter, . . . are also endowed with the power of increasing the organic force from unknown external sources, while animals also in their turn would generate the organic force from their nutriment under the influence of the vital stimuli, and distribute it to the germs during propagation. Whether during life the organic force, as well as the organic matter, is constantly suffering destruction is quite unknown. This much, however, seems certain, that at the death of organic bodies, the vital force is resolved into its general natural causes, from which it appears to be generated anew in plants. If this increase of the vital principle in existing organized bodies from unknown sources in the external world be not admitted, it must be supposed that the apparently endless multiplication of the vital force in the process of growth and in propagation is merely an evolution of germs encased one within the other, or it must be admitted that the division of the organic force which takes place in propagation does not weaken its intensity - a supposition which appears absurd. But the fact would still remain, that by the death of organized bodies organic force is constantly becoming inert or resolved into its general physical causes."46

As exemplified in this passage, the way whereby. Müller formulated a version of the conservation of force or Energie was by considering the problem of generation. The essential problem, as he saw it, was that in propagating their own kind, living organisms must share out their vitality, their force, or power. ${ }^{47}$ Yet the intensity of

43 Op. cit., note 35 above, from the lengthy and important 'Prolegomena' p. 57.

44 Ibid., p. 58.

45 There was a close connexion between the emergence of ideas related to the correlation of forces and the conservation of energy, and the refutation of the possibility of perpetual motion. This is discussed in Kuhn and Elkana, op. cit., note 5 (viii) above, and in my Ph.D. thesis, op. cit., note 3 above.

46 Op. cit., note 35 above, p. 50.

47 This concern for the dynamical aspect of reproduction, namely what happens to the vital force when an individual gives birth to a new individual, was by no means unique to Müller. Clearly, he drew on a long tradition of discussing this question. In my Ph.D. thesis, op. cit., note 3 above, I discuss three of his 


\section{The role of force or power in Liebig's physiological chemistry}

such power never seemed to decline from one generation to the next. How could something be divided in such a way that each fraction is as large or intense as the original whole, without positing a perpetual creation? Clearly, the only reasonable alternative, he said, was continual replenishment of that which is divided, namely of vitality or organic force. That was a principal function of nutrition and, though less explicitly, of respiration in his physiology.

Müller found this account satisfying not only from a physiological, "scientific" point of view, but also philosophically. In volume II of Human physiology it became clear that two of his philosophical mentors were Giordano Bruno (1548-1600) and Benedict Spinoza (1632-1677). (Actually, Spinoza had emerged already as one of his mentors, in his second publication in 1826, Ueber die phantastischen Gesichtserscheinungen [on fantastical sight-perceptions].). 48 Towards the end of his treatise Müller wrote a section on 'Cosmological systems', where he discussed several hypotheses on the connexion of mind with matter. Beginning with a survey of the philosophies and theories of psychology of Aristotle, Bruno, Spinoza, Schelling, Hegel, and Herbart, he discussed issues like the nature of the vital principle, the psychic principle, and the soul. The two principal hypotheses on the soul and its relation to the body that he discussed were the "Platonic-Christian" one, and "Panpsychism". The commoner of the two was the former, according to which the spirit, soul, or vital principle leaves the body at its death and returns to its divine source. For Müller the main difficulty in this doctrine was that life and mind, not being latent properties of matter, did not seem capable of being replenished from any physical sources during the propagation of living creatures; it was the problem of generation or reproduction again. This doctrine, he felt, was one ". . . which, contrary to every attribute of matter, renders them [living organisms] capable of division ad infinitum without any diminution of their power or intensity. Such a property it is certainly difficult for the mind to conceive." 49

The alternative hypothesis, the pantheistic view of a universal spirit, Müller found easier to conceive for it explained the growth and transmission of organic force more plausibly than the first. Citing mainly Bruno, Müller argued that organic force emanates ultimately from the creative spirit or force of God; that as soon as inanimate matter comes within the influence of this creative spirit acting in the guise of vitality, its capacity for life, hitherto latent, becomes manifest. Consequently, the assimilation of new matter into an organism gives rise to an increase in its content of organic force. Hence, organisms can reproduce and their organic force can be transmitted from generation to generation. That this view had direct implications for his physiology, and that his physiology had a largely dynamical nature, can be seen in the following extract (it is useful to have the German original in this instance):

"Das Verhältniss der geistigen Kräfte zur Materie weicht nur darum von dem Verhältniss anderer physischer Kräfte zur Materie ab, dass die geistigen Kräfte nur in den organischen und insbesondere thierischen Körpern vorkommen, und sich nur

physiologist-contemporaries who were keenly interested in the question, Friedrich Blumenbach (17521840), Wilhelm Hufeland (1762-1836), and Friedrich Tiedemann (1781-1861).

48 J. Müller, Ueber die phantastischen Gesichtserscheinungen, Coblenz, J. Hölscher, 1826.

49 Op. cit., note 35 above, p. 1339. 
auf ihre gleichen Producte fortpflanzen, die allgemeinen physischen Kräfte, die man. auch imponderable Materien nennt, eine viel allgemeinere Wirkung und Verbreitung in der Natur haben. Da indessen die organischen Körper auch in der unorganischen Natur wurzeln, und aus ihr zehren, indem die Thiere von Thieren und Pflanzen, die Pflanzen aber theils von unorganischen Stoffen sich ernähren und dabei wachsen und sich multipliciren, so bleibt es ungewiss, ob nicht selbst auch die Anlage zu geistigen Wirkungen, wie die allgemeinen physischen Kräfte in aller Materie vorhanden ist, und durch die vorhandenen Structuren zur Aeusserung in bestimmter Weise kommt." 50 (The relationship of the spiritual forces to matter differs only from the relationship of the other physical forces to matter, in that the spiritual forces appear only in organic and especially animal bodies and propagate themselves only to similar products, [whereas] the general physical forces, which are also called imponderable matters, have a much more general effect and distribution in nature. As however, the organic bodies also take root in inorganic nature and draw upon it, inasmuch as animals [draw] from animals and plants, and plants nourish themselves partly from inorganic matter and thereby grow and multiply, so it remains uncertain whether or not the basis of spiritual actions, like the general physical forces, is present in all matter and comes into view in a definite way through the available structures [of the brain, nerves, etc.].)

Müller's ideas on forces clearly still owed much to his rearing in Naturphilosophie. That issue does not concern us here. ${ }^{51}$ What does concern us was his belief that force could not be sui generis. Furthermore, he asserted that: "Phenomena analogous to such a conditional manifestation of a principle of vital content in all matter are known in physical science. Forces or principles such as electricity and light, for example, which are present in a latent state in bodies are manifested when these bodies are subjected to certain conditions." 52

This view could be compared with others available at that time. Müller compared it with that of the eminent anatomist Johann Christian Reil (1759-1813), whose ideas on vital force were widely known and discussed in the early nineteenth century. ${ }^{53}$ Reil had suggested that the characteristics and powers of organisms are the results of the mode of combination of their chemical elements, that form and composition are the primary factors in differentiating life from non-life, but that until such factors had been elucidated, physiologists could use the term Lebenskraft as a provisional, heuristic label. Some of Reil's contemporaries, Karl Asmund Rudolfi (1771-1832) for instance,

50 Ibid., first German edition, p. 553.

51 The dependence of much early nineteenth-century science on Naturphilosophie is too large and intricate a topic to be discussed in this paper. I can only refer to a few papers in which it has been dealt with and that I have found useful: (i) E. Mendelsohn, 'The biological sciences in the nineteenth century', Hist. Sci. , 1960, 3: 39-59. (ii) B. Gower, 'Speculation in physics: the history and practice of Naturphilosophie', Stud. Hist. Phil. Sci. , 1973, 3: 301-356. (iii) L. Pearce Williams, 'Kant, Naturphilosophie and scientific method', in R. N. Giere and R. S. Westfall (editors), Foundations of scientific method: the nineteenth century, Bloomington, Indiana University Press, 1974, pp. 3-22.

52 Op. cit., note 35 above, pp. 1341-1342.

53 There is a useful, brief discussion of Reil's vital force by M. Teich, 'The historical foundations of modern biochemistry', in J. Needham (editor), The chemistry of life. Eight lectures on the history of biochemistry, Cambridge University Press, 1970, pp. 171-191. 


\section{The role of force or power in Liebig's physiological chemistry}

were greatly impressed by his idea. But not Müller. Müller argued that since the chemical composition and form of an organism must be the same immediately after death as immediately before, the life-principle had to be something over and above mere form. Whereas Reil seemed to envisage life in essentially material terms, Müller leaned towards a dynamical explanation which transcended composition and form. However, Müller was anxious to keep his ideas firmly on the ground of experimental science; with characteristic frankness he admitted that

"Whether this principle is to be regarded as imponderable matter or as force is just as uncertain as the same question is in reference to several important phenomena in physics; physiology in this case is not behind the other natural sciences, for the properties of this principle in the functions of the nerves are nearly as well known as those of light, caloric, and electricity in physics." 54

One clear message, therefore, which emerged from Human physiology was that much the same type of enquiry was needed in physiology as in other sciences and that the sciences would be of mutual benefit especially in elucidating the nature of the imponderable agents. As we know, this message soon became the programme of a handful of his most gifted pupils; by 1841 DuBois Reymond was quoting with approval the Marquis Dutrochet (1776-1847), that "The more one advances in the knowledge of physiology, the more reasons one will have for stopping to believe that the phenomena of life are essentially different from the physical phenomena." 55

And in 1842, Carl Ludwig (1816-1895) ${ }^{56}$ formulated the reductionist programme for himself, Brücke, DuBois Reymond, and Helmholtz, that "We four imagined that we should constitute physiology on chemico-physical foundations and give it equal scientific rank with physics." 57

That was precisely the programme that Liebig advocated in his Agricultural chemistry and, more specifically, in his Animal chemistry. Liebig, however, was never able to rid his physiology of a vital force. Neither was Müller. Müller's struggle over this issue seems to have been mirrored in Liebig's own struggle with it. We shall presently examine that struggle in Animal chemistry, but one more aspect of Müller's physiology needs to be examined - his ideas on stimulus.

Müller envisaged two types of stimulus which could incite a living organism to act. The less important type consisted of agents which merely prodded an organism into activity without contributing to its internal dynamics. By and large, these are what the eighteenth- and early nineteenth-century physiologists had in mind when using words like "stimulus" and "stimulant". The second type of stimulus was much more

\footnotetext{
54 Op. cit., note 35 above, p. 27. In Baly's translation the first sentence goes "Whether this principle is to be regarded as imponderable matter or as force or energy, . . ." Müller's original, however, does not have "or energy"; it goes "Ob man sich diess Princip als imponderable Materie oder als Kraft zu denken habe, . . . . " It would be useful to know why Baly felt the need to add "or energy"; he clearly felt it necessary to differentiate between force and energy, but as that was in $1838 \mathrm{I}$ find it surprising.

55 Cited by V. Kruta in his article on 'Dutrochet', in C. G. Gillispie (editor), Dictionary of scientific biography, New York, Charles Scribner's Sons, 1971, vol. 4, p. 265.

56 Ludwig was not a pupil of Müller, although he allied himself with the reductionistic programme of Helmholtz et al. He received almost all his medical training at Marburg and Erlangen.

57 Cited by Owsei Temkin, 'Materialism in French and German physiology of the early nineteenth century', Bull. Hist. Med., 1946, 20: 322-327.
} 


\section{Vance M. D. Hall}

important to Müller's physiology; these were the truly vital stimuli, for they provided an organism with power as well as provoking it into action. They produced two levels of change in the vital economy - the purely chemical, material changes that are seen to occur throughout life, and the interchanges of force which occur between a living system and its environment. Such vital stimuli were therefore the pabulum vitae in both a material and a dynamical sense; hence, Müller believed that one might truly compare the organism with a piece of pure mechanism or a flame:

"The external conditions which are necessary to life - caloric, water, atmosphere air, and nutriment - at the same time that they maintain life, induce constant changes in the composition of the organized body, themselves combining with the body, while certain old components are decomposed and cast off. These external agents have been called vital stimuli . . . . These vital stimuli produce the phenomena of life by effecting material changes, by producing an interchange of ponderable and imponderable matters... .

"The stimuli are, as it were, the external force which sets in motion the wheels of the whole machine; and although the comparison of the animal body with a machine may not be very apt, yet the organic principle is incapable of activity without this external impulse and without the constant material changes effected by the aid of the external vital stimuli. Richerand has therefore, not inaptly, compared the manifestation of life with the phenomenon of combustion and flame." 58

This line of thought took him close to the idea that vital force, or at least the phenomena of life, might be attributable ultimately to the chemical transformations and the release of chemical force which occur continuously in living organisms. He did not move as far in this direction as Liebig would, but their common direction is undeniable. The closest Müller got to proposing the chemical source of vital powers was in a passage about animal excretions:

"As these excretions are constant, even when the supply of nutrient is stopped, it necessarily follows that a constant decomposition of the substance of the body is essentially connected with life. It cannot, indeed, be otherwise if it be true, as it has already been proved to be, that the vital force is manifested in an animal body only while certain vital stimuli produce in the living tissues constant material changes, of which the phenomena of life are merely the external signs, just as flame is the appearance resulting from the material changes effected in combustion." 59

In another passage he asserted that a key role in these material changes in living tissues was played by respiration. 60 One cannot avoid recalling that nine years later in his Animal chemistry Liebig was to make his pivotal declaration that "respiration is the bent spring which keeps the clock [i.e., the living animal] in motion."61

58 Op. cit., note 35 above, pp. 29-30.

59 Ibid., p. 38.

60 Ibid., p. 38.

61 Liebig, op. cit., note 21 above, p. 27. 


\section{The role of force or power in Liebig's physiological chemistry}

Turning now to Liebig's Animal chemistry in detail, we find the most conspicuous discussions on dynamics in Parts I and III. ${ }^{62}$ However, the Preface is also noteworthy, for there he delineated the general course that physiology would have to follow if it were to advance alongside physics and chemistry. In that delineation Liebig revealed certain ideas and a particular approach to physiology, which we have seen in Müller and which became familiar throughout the rest of Liebig's work whenever he discussed the nature of life. He declared that

"The most beautiful and elevated problem for the human intellect, the discovery of the laws of vitality, cannot be resolved, nay, cannot even be imagined, without an accurate knowledge of chemical forces; of those forces which do not act at sensible distances; which are manifested in the same way as those ultimate causes by which the vital phenomena are determined; and which are invariably found active, wherever dissimilar substances come into contact." 63

When we come to Part I, we find the first dozen pages preoccupied with forces. Part I opens with the following assertion.

"In the animal ovum, as well as in the seed of a plant, we recognize a certain remarkable force, the source of growth, or increase in the mass, and of reproduction, or of supply of the matter consumed; a force in a state of rest. By the action of external influences, by the presence of air and moisture, the condition of static equilibrium of this force is disturbed; entering into a state of motion or activity, it exhibits itself in the production of a series of forms . . . This force is called the vital force, vis vitae or vitality. "64

Although the next few pages presented a rather tortuous and tentative view of the dynamics of the living organism, from which one gets the impression that Liebig was trying to feel his way across disputed and difficult ground, 65 a few definite ideas did emerge. One was that vis vitae, despite its inscrutability, had as much right to the attention of natural philosophers as did light, electricity, and magnetism. ${ }^{66}$ Another idea was that life, or vital force, is not sui generis but depends on, or is intimately associated with, chemical force. His exact view of this relationship is difficult to determine; the key passages are as follows: "In order to keep up the phenomena of life in animals, certain matters are required, parts of organisms, which we call nourishment. In consequence of a series of alterations, they serve either for the increase of the mass (nutrition), or for the supply of the matter consumed (reproduction), or finally, for the production of force." 67 And on the same page: "All vital activity arises

62 Lipman, op. cit., note 5 (vi) above, p. 174, asserts that Liebig hardly mentioned vital force in Parts I and II of Animal chemistry. While this is true of Part II, it is clearly not true of Part I, although after the first 30 pages or so, vital force is mentioned rarely.

63 Liebig, op. cit., note 21 above, p. XXIX.

64 Ibid., p. 1.

65 This assessment of Liebig's ideas on vital force agrees with Lipman's. See particularly Lipman, op. cit., note 5 (vi) above, pp. 182-185. It is difficult to reconcile these early passages of Animal chemistry with Glas's interpretation, op. cit., note 5 (xi) above, p. 303 and elsewhere.

66 Liebig, op. cit., note 21 above, p. 7.

67 Ibid., p. 9. 


\section{Vance M. D. Hall}

from the mutual action of the oxygen of the atmosphere and the elements of the food."

"In the processes of nutrition and reproduction, we perceive the passage of matter from the state of motion to that of rest (static equilibrium); under the influence of the nervous system, this matter enters again into a state of motion. The ultimate causes of these different conditions of the vital force are chemical forces." 68

From these and other passages we can infer that Liebig was adopting an essentially dynamical view of the living organism, a view far different from the application of mere chemical analyses and hypothetical syntheses that some historians have regarded as the characteristic of Animal chemistry. ${ }^{69}$ The latter characterization, of course, has had some justification: First, one of the foci of dispute over Animal chemistry was Liebig's innovation of chemical equations for metabolic processes, a technique that Jöns Jacob Berzelius (1779-1848) scorned as "writing-table physiology". ${ }^{70}$ This clearly was an issue concerning chemical analyses and hypothetical syntheses. Second, very few of the reviewers and commentators mentioned the dynamical ideas in the book. ${ }^{71}$ Neither did Liebig's obituarists discuss his vitalism or his general ideas on force. 72 The reason for the first omission was almost certainly that his dynamical ideas were considerably less startling and innovatory than other features of the work; for instance, as we have seen, Müller's Human physiology contained a number of ideas on force which appeared in Animal chemistry, but only the latter contained the new brand of chemical bookkeeping which used so many chemical formulae and equations. A reason for the second omission by his obituarists, was probably that Animal chemistry marked the apotheosis of Liebig's interest in force, an interest which had become obscured by the end of his career by his work in analytical chemistry and his international reputation as a teacher. Besides, as I shall discuss at the end of this paper, his ideas on vital force were decidedly non- $U$ by the time of his death, and no obituarist would have wanted to draw attention to them.

This losing-sight of Liebig's vitalism in particular and of his dynamics in general is paradoxical, not only because they were key interests in his early agricultural and physiological chemistry, but also because they seemed set to provide him with a substantial basis for further research. As Lipman asserted, ${ }^{73}$ Liebig's vitalism was thoroughly scientific: indeed, he regarded vital force not as a hindrance to experiment but rather as a concept which accorded with scientific law and promised to stimulate further research. He argued that since science would never know the essence of the causes of light, electricity, or magnetism, because these were only concepts in the mind, whose laws, however, could be known as they were manifested in phenomena, so too

68 Ibid., p. 9.

69 See for instance Glas, op. cit., note $5(\mathrm{x})$ above, where he contrasts Liebig's mechanical theory of fermentation with the apparently more dynamical theory of Mulder. One also gets this impression from $M$. Florkin, A history of biochemistry, vol. 30 of Comprehensive biochemistry, Amsterdam, Elsevier, 1972. In contrast, considerable notice of Liebig's dynamical concern is taken in N. G. Coley, From animal chemistry to biochemistry, Amersham, Hulton Educational, 1973, pp. 119-143.

70 J. J. Berzelius, Jahres-bericht über die Fortschritte der physichen Wissenschaften, Tübingen, 1843, 22: 535.

71 See the section on 'Reception of Liebig's Animal chemistry' in Holmes, op. cit., note 5 (iv) above, pp. LVIII-LXXIII. Lipman, op. cit., note 5 (v) above, discusses a few reactions to his vital force.

72 See notes $162,163,164,165$ and 166 below.

73 Lipman, op cit., note 5 (vi) above, pp. 176-177. 
the essence of the vital force would never be known although its laws could be. And since such laws were the guarantors of forces, the laws of vitality guaranteed the reality of vital force. The clearest example in Animal chemistry of how a due regard for force and its laws might direct and benefit research into a physiological phenomenon was his discussion of respiration. This section of Part I so well exemplifies his dynamics and so closely resembles Müller's approach that it is indispensable to our understanding of his aims in physiology:

"Respiration is the falling weight, the bent spring, which keeps the clock in motion; the inspirations and expirations are the strokes of the pendulum which regulate it. In our ordinary time-pieces, we know with mathematical accuracy the effect produced on their rate of going, by changes in the length of the pendulum or in the external temperature. Few, however, have a clear conception of the influence of air and temperature on the health of the human body; and yet the research into the conditions necessary to keep it in the normal state is not more difficult than in the case of a clock.

"V. The want of a just conception of force and effect, and of the connexion of natural phenomena, has led chemists to attribute a part of the heat generated in the animal body to the action of the nervous system. If this view exclude chemical action, or changes in the arrangement of the elementary particles, as a condition of nervous agency, it means nothing else than to derive the presence of motion, the manifestation of a force from nothing. But no force, no power, can come of nothing."74

In my opinion, the rest of Animal chemistry was but a filling-out of this declaration. Animal chemistry was not essentially a textbook of chemistry in our usual sense of chemistry; rather it was a treatise on force. Three ideas on force which appeared early in it were: the intimate connexion between forces within and outside the living organism, the intimate relationship among all forces (which we can recognize as a type of correlation of forces), and the non-creatibility and indestructibility of force or power. We can see these themes, for instance, in his discussion of animal heat:

"The observation has been made, that heat is produced by the contraction of the muscles, just as in a piece of caoutchouc which, when rapidly drawn out, forcibly contracts again with disengagement of heat. Some have gone so far as to ascribe a part of the animal heat to the mechanical motions of the body, as if these motions could exist without an expenditure of force consumed in producing them; how then, we may ask, is this force produced?

"By the combustion of carbon, by the solution of a metal in an acid, by the combination of the two electricities, positive and negative, by the absorption of light, and even by the rubbing of two solid bodies together with a certain degree of rapidity, heat may be produced.

"By a number of causes, in appearance entirely distinct, we can thus produce one and the same effect. ... In all such cases we have a something given, which merely 74 Liebig, op. cit., note 21 above, pp. 27-28. 


\section{Vance M. D. Hall}

takes another form; in all we have a force and its effect. By means of the fire which heats the boiler of a steam-engine we can produce every kind of motion, and by a certain amount of motion we can produce fire.

“. . . But, admitting all the influence which electric or magnetic disturbances in the animal body can have on the functions of its organs, still the ultimate cause of all these forces is a change of condition in material particles, which may be expressed by the conversion, within a certain time, of the elements of the food into oxidized products. Such of these elements as do not undergo this process of slow combustion are given off unburned or incombustible in the excrements." 75

He went on to discuss various methods for producing heat - by motion, by galvanic current and by contraction of muscles. ${ }^{76}$ All these processes entailed the dependence of one cause upon another: magnetic force depended upon the activity of electrical force which in turn depended upon chemical action. 77 All this led to one of his most reductionistic statements on vitality:

"There are various causes by which force or motion may be produced. A bent spring, a current of air, the fall of water, fire applied to a boiler, the solution of a metal in an acid - all these different causes of motion may be made to produce the same effect. But in the animal body we recognize as the ultimate cause of all force only one cause, the chemical action which the elements of the food and the oxygen of the air mutally exercise on each other. The only known ultimate cause of vital force, either in animals or in plants, is a chemical process. If this be prevented, the phenomena of life do not manifest themselves, or they cease to be recognizable by our senses. If the chemical action be impeded, the vital phenomena must take new forms."78

As most Liebig scholars are aware, such absence of equivocation on the vital force was rare in his writings. Indeed, the view advanced here was apparently weakened, even contradicted, in other passages in Animal chemistry. ${ }^{79}$ But the themes of the intimate relationship among all forces and of the principle of causality in all phenomena of force and action (Thätigkeit and Bewegung) persisted throughout.

These themes are especially strong in Part III of Animal chemistry, the part that Lipman and others have discussed most. Indeed, Part III contained much more on force than did Part I. Part III also contained several passages on the conservation of motion often accompanied by expressions, some vague but others quite precise, of the conservation of forces within the organism. Actually, Liebig usually expressed this latter idea as conservation of the momentum of force, (Kraftmoment), meaning the work that a moving force could do. This is one occasion when the original is obviously so important, besides being difficult to translate precisely, that it should be quoted in

75 Ibid., p. 31 .

76 Ibid., p. 31 .

77 Ibid., p. 32.

78 Ibid., p. 32.

79 See for instance some of Liebig's statements on nervous force, ibid., pp. 3-4. Also the paragraph which begins "If we assume, that all the phenomena exhibited by the organism of plants and animals are to be ascribed to a peculiar cause ...." p. 8. In the first half-dozen pages of Part III there are also some comments that are difficult to reconcile with other, more reductionistic ones. 


\section{The role of force or power in Liebig's physiological chemistry}

Liebig's own words: "Die Wirkung ist folglich nicht der bewegenden Kraft allein, noch der Zeit allein, sondern dem Druck, multipliciert mit der Zeit=Kraftmoment, proportional." 80

This was one of his several attempts to differentiate between what today we call force on the one hand and work or energy on the other. A fuller attempt occurred a few pages later:

"Wir wissen, dass dieses Bewegungsmoment der Lebenskraft in einem belebten Körpertheil verwendbar ist, um ruhenden Materien Bewegung $\mathrm{zu}$ ertheilen (Zersetzung zu bewirken, Widerstände aufzuheben), und wenn die Lebenskraft in ihren Aeuserungen sich ährlich verhält wie andere Kräfte, so muss dieses Bewegungsmoment mitgetheilt oder fortgepflanzt werden können durch Materien, die in sich selbst durch eine entgegenwirkende Thätigkeit seine freie Aeuserung nicht aufheben." 81 (We know that this momentum of motion in the vital force, residing in a living part, may be employed in giving motion to bodies at rest (that is, in causing decomposition, or overcoming resistance), and if the vital force resembles other forces in its manifestations, this momentum of force must be able to be conveyed or communicated by material bodies, which in themselves do not destroy its effect by an opposite manifestation of force.)

On motion itself, he asserted that it cannot be annihilated even though it might become inappreciable to human sense. ${ }^{82}$ Liebig went on to suggest that the usual conceptions of motion, equilibrium, and resistance could be extended to chemical force and thence to vital force, for he believed that the modus operandi of vital force was infinitely closer to that of chemical force than any other type of force. In explicating "the phenomena of motion in the animal organism", he began by considering the voltaic cell, in which the fundamental role of chemical force was clear. An important feature of this discussion and of other discussions in the treatise was the absence of Naturphilosophie-type speculation on the theoretical or metaphysical foundations of these transformations of forces. Such speculations were characterisitic of men like Hans Christian Oersted (1777-1851) and Ludwig August Colding (1815-1888), to mention two figures whom Kuhn discussed as contributors to the correlation and conservation theories, but they were not characteristic of Liebig. In fact Liebig went so far as to emphasize that "In the preceding paragraphs we have considered these remarkable phenomena in a form which is independent of the explanations of the schools . . . All the suppositions which may be employed as explanations of the phenomena have not the slightest influence on the truth of these phenomena; for they merely refer to the form in which they are manifested." 83

According to Liebig, the generator of force for motion in the animal was muscular tissue; the role of vital force was to transmit the "moving forces" from one tissue or limb to another tissue or limb, and to induce a chemical change in the recipient tissue. The latter lost some of its vitality as a result of its chemical change since, as he had

80 Ibid., original German edition, p. 206.

81 Ibid., original German edition, pp. 208-209. In the Holmes edition, p. 194.

82 Ibid., Holmes edition, p. 194.

83 Ibid., p. 207. 
explained in Agricultural chemistry, vital force was a consequence or phenomenon of particular forms of matter which depended upon particular chemical compositions. This was essentially Reil's theory, although Liebig did not say so. In Liebig's own words: "A living part acquires, on the above supposition, the capacity of offering and overcoming resistance, by the combination of its elementary particles in a certain form; and as long as its form and composition are not destroyed by opposing forces, it must retain its force uninterrupted and unimpaired." 84

Since any change in muscular composition and form entailed a concomitant diminution in its stock of vital force, there immediately arose an imbalance between the chemical forces inherent in the tissue's composition and its vital force. Since chemical forces, especially those possessed by oxygen in the blood, tended continuously to break down or oxidize living tissues, that portion of muscle which lost its vitality would speedily be oxidized. The net process was that the change of form of muscle tissue generated mechanical force, just as the chemical changes in the voltaic cell generated mechanical force. Moreover, since vital force initiated the former change, one could say that vital force generated an equivalent amount of mechanical force. 85

This synopsis of Liebig's theory of animal motion differs slightly, but not importantly, from the analyses of other Liebig scholars. 86 One feature, however, that has often been overlooked was Liebig's persistent effort to express his theory rigorously and quantitatively. This persistence indicates how crucial such dynamics were to his physiology. These efforts can be seen especially well in a few extraordinary pages in Part III where he deduced a set of rules on force and motion in animals. These rules clearly followed from the physiological and chemical data he had been discussing in previous pages. Several of them were as follows:

"For every proportion of oxygen which enters into combination in the body, a corresponding proportion of heat must be generated.

"The sum of force available for mechanical purposes must be equal to the sum of the vital forces of all tissues adapted to the change of matter.

"If, in equal times, unequal quantities of oxygen are consumed, the result is obvious, in an unequal amount of heat liberated, and of mechanical force.

"When unequal amounts of mechanical force are expended, this determines the absorption of corresponding and unequal quantities of oxygen.

"For the conversion of living tissues into lifeless compounds, and for the combination of oxygen with such constituents of the body as have an affinity for it, time is required.

84 Ibid., p. 199.

85 Ibid., pp. 221-242.

86 The fullest discussion is to be found in Lipman, op. cit., note 5 (vi) above. There are only a few minor issues where Lipman's discussion needs to be supplemented or modified. For instance, I do not think he discussed sufficiently the relation between Liebig's vital force and chemical force, nor the role of Kantian ideas on force and causality. (The latter is a task which still needs to be done: an attempt can be found in my Ph.D. thesis, op. cit., note 3 above, chapters 10 and 14. Elkana has discussed briefly the Kantian background, but only with reference really to Helmholtz; op. cit., note 5 (viii) above, chapter VII.) Another comment on Lipman is that whilst I agree with his assertion that Liebig's religion was not necessary to his belief in a vital force, op cit., note 5 (vi) above, p. 185, his comments have been superseded by the paper by Otto Sonntag, 'Religion and science in the thought of Liebig', Ambix, 1977, 24: 159-169. 
The role of force or power in Liebig's physiological chemistry

"In a given time, only a limited amount of mechanical force can be manifested, and only a limited amount of heat can be liberated.

"That which is expended in mechanical efforts, in the shape of velocity, is lost in time, that is to say, the more rapid the motions are, the sooner or the more quickly is the force exhausted.

"The sum of the mechanical force produced in a given time is equal to the sum of force necessary, during the same time, to produce the voluntary and involuntary motions; that is, all the force which the heart, intestines, etc., require for their motions is lost to the voluntary motions.

"The amount of living matter, which in the body loses the condition of life, is, in equal temperatures, directly proportional to the mechanical effects produced in a given time." 87

Furthermore, such proportionalities could be related to chemical measurements that might be done on animal metabolism, for instance the rate of excretion of nitrogen in urine. Since, according to Liebig's theory of nitrogen metabolism, the physical activity of an animal was proportional to the degradation or "metamorphosis" of its nitrogenous tissues, physical activity or the production of mechanical force might be measured in terms of nitrogen voided in the animal's urine. 88 Similarily, the accumulation of vital force, for instance in the growth of a young animal, could be measured in terms of the excess of chemical input over chemical output in the processes of nutrition and excretion. If the rate of intake of matter exceeded the rate of elimination of waste-products in a living organism, that organism would grow; and it would grow not only in sheer bulk but also in its stock of vitality, for it would be taking in more chemical force than it would be eliminating. Hence, another set of his extraordinary rules was that:

"Growth, or the increase of mass, stands at every age in a fixed relation to the amount of vital force consumed as moving power.

"The vital force, which is expended for mechanical purposes, is subtracted from the sum of the force available for the purpose of increase of mass.

"The active force, which is consumed in the body in overcoming resistance (in causing increase of mass), cannot at the same time be employed to produce mechanical effects.

"Hence it follows necessarily, that when, as in childhood, the supply exceeds the waste of matter, the mechanical effects produced must be less in the same proportion.

"With the increase of mechanical effects produced, the capacity of increase of mass or of the supply of waste in living tissues must diminish in the same proportion." 89

With these "rules" Liebig was able to give dynamical definitions for a variety of

87 Liebig, op. cit., note 21 above, pp. 232-233.

88 Ibid., p. 233.

89 Ibid., p. 234 
living processes: growth in childhood, old age, ${ }^{90}$ the need for sleep, ${ }^{91}$ animal heat, ${ }^{92}$ disease, ${ }^{93}$ fevers, ${ }^{94}$ etc. Despite the ambiguities and tortuosities of these passages, one idea emerged clearly: the living organism is essentially a dynamical system in which the same laws of force and of causality apply as in the inorganic world. One of these laws was that there is a "metamorphosis" or interdependence among all forces. Another was at least implied, namely that force cannot be created or destroyed. These ideas can be seen especially clearly in the following extract:

"The change of matter, the manifestation of mechanical force, and the absorption of oxygen are, in the animal body, so closely connected with each other, that we may consider the amounts of motion, and the quantity of living tissue transformed, as proportional to the quantity of oxygen inspired and consumed in a given time by the animal. For a certain amount of motion, for a certain proportion of vital force consumed as mechanical force, an equivalent of chemical force is manifested; that is, an equivalent of oxygen enters into combination with the substance of the organ which has lost the vital force; and a corresponding proportion of the substance of the organ is separated from the living tissue in the shape of an oxidized compound." 95

As these passages from Animal chemistry show, and as Lipman, Elkana, and others have argued, Liebig considered his vital force to be a thoroughly respectable and scientific agent. Far from envisaging it as infringing all the known laws of force and motion (such as the impossibility of a perpetuum mobile), he tried to correlate it with the other dynamical agents in Nature. The organism thus became a powerhouse in which the "momentum of force" or power-output, could never be greater than the powerinput; if output and input were balanced perfectly, good health and physiological equilibrium resulted; if input exceeded output, growth resulted;96 if output exceeded input, the organism would decline in strength and would eventually die.

\section{IV}

Turning now to his populist publication, Familiar letters on chemistry, 97 which at least one late nineteenth-century encyclopaedia ${ }^{98}$ called his most memorable work, we find several letters dealing with force or power. Although the first edition appeared in 1844 , that is a few years after Grove, Joule, and Mayer had first announced their ideas

\footnotetext{
90 Ibid., pp. 236-237.

91 Ibid., pp. 235-239; also p. 217.

92 Ibid., pp. 240-242.

93 Ibid., pp. 242-253. See also Pelling, op. cit., note 24 above, for a very useful discussion of Liebig's theory of disease.

94 Ibid., pp. 244-245.

95 Ibid., pp. 211-212.

96 Once again, Liebig's ideas in physiology depended more than he was prepared to admit on the ideas of previous physiologists. The view that growth, good health, and physiological equilibrium depend upon a quasi-dynamical balance between input and output can be found in the late eighteenth- early nineteenthcentury physiologies of Blumenbach, Hufeland, and Tiedemann, as I argued in chapters 11 and 12 of my Ph.D. thesis. Cf. note 47 above.

97 J. Liebig, Chemische Briefe, Heidelberg, C. F. Winter, 1844. Unless otherwise stipulated, I shall cite the English translation by J. Gardner, Familiar letters on chemistry, London, Taylor \& Walton, 1844.

98 The national encyclopaedia, London, Wm. Mackenzie, c. 1890, vol. 8, p. 377.
} 


\section{The role of force or power in Liebig's physiological chemistry}

on force, Liebig almost certainly owed nothing to them; almost certainly, he did not know of Grove's and Joule's studies, and although Mayer had published in his Annalen, ${ }^{99}$ it is unlikely, as Kuhn argued, 100 that Liebig realized the import of Mayer's ideas at that time. Therefore, what he wrote about the connexions among forces in the first edition of Familiar letters was probably largely original; certainly, it resembled closely his ideas in Agricultural and Animal chemistry.

In Letter VII, 'On mechanical forces', Liebig ranged vital force alongside the other forces of Nature. Vital force was simply another force, to be regarded much as one regarded other forces. Thus:

"Light, Heat, the Vital Principle, and the Force of Gravity exercise a most decided influence upon the number of the simple atoms which unite to form a compound atom, and upon the manner of their arrangement. They determine the form, properties, the characteristic qualities of the combinations, precisely because they are able to communicate motion to atoms at rest, and to annihilate motion by resistance.

"Light, heat, the vital principle, the electric and magnetic forces, the power of gravity, manifest themselves as forces of motion and of resistance, and as such change the direction and vary the strength of the chemical force."101

Letter VIII, 'The vital principle', dealt explicitly with connexions among forces. Although it did not use the word "correlation" or any synonym for it, it asserted the intimacy of the interactions between the vital force and all other forces and emphasized their fundamental similarity, repeating the arguments that had been used in his earlier treatises.

Letter IX, 'Transformations of almond milk', discussed the vitalism-mechanicism issue with particular regard to fermentation. No new arguments on force were advanced. Indeed, the foremost assertion was on the conservation of motion which, as we saw in Agricultural chemistry, Liebig had attributed to Laplace and Berthollet. This principle, that an atom or molecule put in motion by any power whatever would communicate its motion to atoms in contact with it, Liebig now extolled as "the greatest and most enduring acquisition which chemical science has derived from the study of fermentation." 102

Throughout this first edition, Liebig seemed to want to discuss not only the main issues in the standard chemistry of his day but also to reveal a truly dynamical point of view, namely to enquire about the causes, the forces, to which were owed "the great and manifold successes of modern times." 103 From other letters we know that by the "manifold successes of modern times" he meant not only the scientific investigation of the concept of force, but also the application of new and immense sources of power to

99 J. R. Mayer, 'Bemerkungen über die Kräfte der unbelebten Natur', Liebig's Annalen der Chemie und Pharmacie, 1842, 42: 239.

$100 \mathrm{Kuhn}$, op. cit., note 1 above, especially some of the footnotes.

101 Liebig, op. cit., note 97 above, p. 112.

102 This feature of Liebig's ideas has been discussed rather rarely by Liebig commentators. Glas, however, has given it considerable attention; op cit., note $5(x)$ above in particular. Lipman has also discussed it.

103 This theme occurs particularly in Letter 1, pp. 1-34. 


\section{Vance M. D. Hall}

industry, war, agriculture, and the general wealth of nations. This concern with the practical aspect of the study of force or power accords with what several Liebig scholars have written about his general concern for the utility of science. For instance, Otto Sonntag has suggested that, although utility was never Liebig's main aim in science, it was a recognizable part of his view of science during the first twenty to twenty-five years of his career, for then he (and others) had felt a need to pit their science against the dominant influence of German Humanism and Naturphilosophie in German education and intellectual life. 104

As can be seen in Animal chemistry and Agricultural chemistry, Liebig followed Newton (probably with Kant in mind too) in denying man's ability to comprehend the nature of force. 105 In the third edition of Familiar letters (1851), which was much longer than the two preceding editions, he developed that theme, asserting that the only fruitful quest in dynamics was for the relations among forces. Now he was prepared to posit, more explicitly than before, a real interdependence or correlation among forces. Thus, in Letter XIX he suggested that, just as naturalists could not define the boundary between plant and animal life, so natural philosophers could not distinguish the boundary between vital and physico-chemical forces. ${ }^{106}$ In Letter XX, on 'The connexion of the sciences', he again declared that the essence of force is inscrutable, though he emphasized that progress had been made in elucidating the "wonderful connexions" among forces, especially between electrical and chemical forces. ${ }^{107}$ In this direction, he felt, lay the future of science. Letter XXI took up this point:

"The history of science gives us the consoling assurance that we shall succeed . . . in unveiling the mysteries of organic life, and that we shall be enabled to obtain decided, definite answers to the question - What are the causes which have a share in producing the vital phenomena? All the peculiarities of bodies, all their properties, are determined by the co-operation of several causes; and it is a problem to be solved by scientific research, to ascertain the proportion in which each individual cause contributes to the effect. In order to attain a knowledge of the mutual relations of these properties, we must endeavour to become acquainted with them and to discover the cases in which they vary. It is a natural law, which admits of no exception, that variations in one property are always and invariably accompanied by uniform and corresponding variations in another property, and it is perfectly obvious that if we know the laws of these variations, we are enabled to deduce one property from another without further observation.

"To ascertain a natural law is nothing more than to ascertain such a relation of

104 O. Sonntag, 'Liebig on Francis Bacon and the utility of science', Ann. Sci. , 1974, 31: 373-386.

$105 \mathrm{On}$ the philosophical background to such discussions on force and causality, see my Ph.D. thesis, op. cit., note 3 above. Chapter 1 is 'On power and force in 17th and 18th century British philosophy'. Chapter 10 is 'On power, causality and relation in the principal Continental philosophies from Descartes to Schelling'. And Chapter 14 is 'On power in the physiological chemistry of Justus Liebig'. Although I would not now agree with some of the interpretations in my thesis, I think that the contents of these three chapters are substantially correct and that Liebig owed most of his philosophy of force and causality to Kant and Newton. However, this is an issue which needs much more analysis.

106 J. Liebig, Familiar letters on chemistry, 3rd ed. trans. by W. Gregory, London. Taylor \& Walton, 1851, p. 247.

107 Ibid., pp. 257-259. 


\section{The role of force or power in Liebig's physiological chemistry}

dependence. Knowledge of the law includes explanations of the phenomenon and an insight into the essence of the forces by which it is determined." 108

All of which was clearly useful, not only to confirm the reality of force, but also to indicate how the vital force might be encompassed within a general study of dynamical relations. He went on to discuss the progress that had been made in discovering the interdependencies among forces - between electrical and magnetic forces, between radiant heat and magnetism, and between electricity and radiant heat. Who could doubt, he asked, that the vital force must also obey the law of dependence and that the physico-chemical properties of an organism play an ascertainable role in vital phenomena?109

In this last letter Liebig seems to have had in mind the studies by Grove, Joule, and others, for this was precisely the patch they had been cultivating. Yet he cited no-one. Actually, he must have been acquainted with their researches, for there were lengthy discussions of them in some of the volumes of the Jahresbericht über die Fortschritte der reinen, pharmaceutischen, und technischen Chemie, Physik, Mineralogie, und Geologie (Annual report on the progress of pure, pharmaceutical and technical chemistry, physics, mineralogy, and geology) in the 1840 s, of which he was a principal editor. For instance, in Volume I (1847) there was a detailed account of experiments by Joule, Dulong, and Séguin to determine the mechanical equivalent of heat. 110 Clearly, the editors of the Annual report considered this an important topic, but it did not seem to them to presage any principle of more fundamental and general import; it was concerned with only two dynamical agents, namely heat and mechanical force. Séguin was the only one of the three, according to the report, whose thoughts had a larger horizon, for he "announces that he is engaged in an extensive series of investigations, in order to determine that the phenomena of heat are only phenomena of motion and consequently subject to the law of general gravitation." 111

The same volume of Annual report carried another discussion of this field at the beginning of its section on kinetics. 112 The discussion began with a review of Grove's publication On the correlations of the physical forces (1846). 113 What is most interesting is that the editor(s) declared that Grove's principal idea, ". . . that each of the following forces, motion, heat, electricity, light, magnetism, and chemical attraction can be connected into all the others, is not altogether new, and perhaps the author has not supported his position with all the materials which were at his disposal . . . ."114

This assessment was unfair. Grove himself did not claim that his theory was original, but he did claim, and justly so, that he had investigated the topic with unprecedented care and detail. Yet the reviewer did not praise the thoroughness of his work. Perhaps the reviewer, whoever he was, had in mind the speculations of the Naturphilosophen on

108 Ibid., p.. 264-265.

109 Ibid., pp. 271-272.

$110 \mathrm{~J}$. Liebig and H. Kopp, Annual report on the progress of chemistry and the allied sciences, edited by A.

W. Hofmann and W. de la Rue, London, Taylor \& Walton, 1849, pp. 41-44.

111 Ibid., p. 42

112 Ibid., p. 93.

113 Grove, op. cit., note 2 above.

114 Op. cit., note 110 above, p. 93. 
the metamorphoses of forces, when he said that Grove's idea was not altogether new. Or perhaps he had in mind the statement of essentially the same idea in the writings of one of the Annual report's editors, namely Liebig. (I have not discovered who wrote the review; it could be most instructive to know.) The reviewer went on to approve Grove's remark that the most important task was to determine the mechanical equivalents of all forces. This task, the reviewer commented, was already being pursued by Joule, Karl Friedrich Gauss (1777-1855), Wilhelm Eduard Weber (18041891), and Carlo Matteucci (1811-1868). A Mr. Robert Leslie Ellis (1817-1859) had also been investigating the relations among forces, albeit in an abstract, mathematical formulation which, though ingenious, was too abstract to merit discussion in the Annual report.

The significance of the Reports for our study of Liebig's dynamics is that he must have known of other men's researches on forces by 1847 at the latest, even though he did not cite them in his own discussions on force in the second or third editions of Familiar letters. Not even Matteucci's work, which had a physiological background, 115 did he cite.

\section{V}

We find this parsimony in citing other investigators in another of Liebig's publications in which force was a prominent theme, his Chemistry and physics in relation to physiology and pathology 116 (1846). This little work has been much neglected by Liebig scholars, probably because those who have been aware of its existence might have dismissed it as a mere populist pamphlet or else regarded it as a repetition of a part of Animal chemistry. ${ }^{117}$ Yet it is worth discussing here, for it presented succinctly Liebig's metaphysic of science and especially of physiology; and that metaphysic was all about force.

115 Carlo Matteucci was then professor of physics at Pavia. In 1844 the government of Tuscany invited him to give a series of lectures on the physical phenomena of living organisms. In these lectures, which relied mostly on his own experimental work, Matteucci aimed to explain living phenomena in terms of physicochemical forces. Although his experiments showed strong analogies between vital processes and inorganic ones, for instance between nerve-force and electricity, Matteucci was too cautious to conclude that there was an exact identity between them. He could not take his reductionism as far as DuBois Reymond's, although he did feel justified in asserting that all forces, vital and inorganic, belong to a single category of agents which could all be studied by the same method. Matteucci's lectures were printed immediately in Italian: Lezioni sui fenomeni fisico-chimici dei corpi viventi, Pisa, Minerva, 1844. A second edition soon appeared (1846), of which he supervised a French translation (1847). The first English edition was Lectures on the physical phenomena of living beings, translated by Jonathan Pereira, London, Longman, Brown, Green \& Longman, 1847. Although his work was not translated into German, it is inconceivable that Liebig did not know of it, for Matteucci had been publishing on animal electricity since 1840, was the editor of Il cimento and Il nuovo cimento in the 1840s, and was certainly known to DuBois Reymond. Indeed, Matteucci was one of the foremost natural philosophers of his time in Italy and his physico-chemical researches in physiology were very well known in Italy, France, and Britain, and probably in Germany. Matteucci's work is discussed, albeit briefly, in my paper on W. B. Carpenter, op. cit., note 39 above.

$116 \mathrm{~J}$. Liebig, Chemistry and physics in relation to physiology and pathology, London, H. Bailliere, 1846.

117 Liebig's Chemistry and physics in relation to physiology and pathology is included in Henry Carrington Bolton's A select bibliographv of chemistry, 1492-1892, Washington, Smithsonian Institution, 1893. It is also in Carlo Paoloni, Justus von Liebig. Eine Bibliographie sämtlicher Veröffentlichungen, Heidelberg, Carl Winter, 1968. Bolton commented that it was "A translation of Theil 2 of Abtheilung 1 of Die Thier-Chemie" (p. 630). Paoloni (p. 132) repeats this assertion. Yet even a cursory comparison between it and Animal chemistry shows that it is not a translation, not even a very free one, of any part of Animal chemistry. I wonder whether Bolton's erroneous description has discouraged historians from reading it. 
There were several themes in Chemistry and physics which relate to this paper: (i) an analysis of causality and Liebig's assertion that physiologists often conflated mere coincidence with causality, and cause with effect;118 (ii) the need for a correct conception of force ; 119 and the natural dependencies among forces; ${ }^{120}$ (iii) the need for a study of dynamical causes in physiology;121 (iv) the conservation of motion;122 (v) the points of contact between chemistry and physiology, these being largely dynamical;123 (vi) the inadequacies of old-fashioned vitalism and of the new reductionism; 124 (vii) the role of vital force. 125

The treatise began with a discussion of the methods and aims of the sciences. One of the principal aims was to be an understanding of relations between natural phenomena (in accordance with Kant), and as this aim would be attained so "chemistry loses the character of an experimental art, [and] so will physiology be capable of ranking as a deductive science." 126 Foremost amongst these relations were the general relation of causality and the particular relations among forces. On these relations alone would physiology acquire a scientific basis. ${ }^{127} \mathrm{~A}$ particular issue in which Liebig felt these dynamical considerations were especially important, yet in which they had been neglected, was the study of irritants or stimulants (one of Müller's key themes although, as usual, Liebig cited no-one). As had Müller, Liebig differentiated between true irritants which contributed to the dynamical or material contents of an organism, and those irritants which of themselves did not contribute anything to the organism. Thus, he wrote: "It is impossible to arrive at the comprehension of a subject, if, as is done by some pathologists, a term - such as an irritant - be made to include alike active causes, which change the form and composition of organic bodies, and such as light, sound, etc., which do not possess this capacity." 128

That these active causes were primarily the physico-chemical forces can be seen in his discussion of current theories of putrefaction, fermentation and contagion. Indeed, his words could not have been less ambiguous: "Although every pathologist and physiologist is fully convinced that no organic process can be explained without the cooperation of chemical and physical forces, every theory which has hitherto been based upon such causes has been invariably doubted and rejected." 129 Among such theories were Liebig's own on fermentation, animal heat, and fever. Although in his previous writings it was not always clear that he was adopting a specifically dynamical point of view, for he often used words like "motion", "impetus", and "transfer of motion" rather than "force" and "energy", it is clear that in Chemistry and physics this was his aim. Thus, in discussing fever he asserted that before any explanation of it could be found,

118 Liebig. op cit., note 116 above, pp. 73-74 especially.

119 Ibid., pp. 9, 10, 29-30, 97, 109 especially.

120 Ibid., pp. 103-104.

121 Ibid., pp. 15, 57, 79, 81, 104, 106-107, 115-116.

122 Ibid., pp. 40-41, 45, 78.

123 Ibid., pp. 90-93 especially.

124 Ibid., pp. 107-109.

125 Ibid., pp. 63-64 especially.

126 Ibid., p. 3.

127 Ibid., p. 15.

128 Ibid., p. 20.

129 Ibid., p. 57. 


\section{Vance M. D. Hall}

"we must arrive at a conception of motion, and seek the source of a moving force and heat in the animal body. If we could trace the cause of fever according to the physical method, and consider that by the co-operation of many, or let us say of two causes, a certain amount of force is engendered in the heart itself, by which the circulation of the blood is affected; then the motion will be regular or normal, if the number of beats of the heart be equal in every minute, and when the force is thus divided over equal periods." 130

Actually, as this extract shows, and as we saw in Agricultural chemistry and Animal chemistry, Liebig's view of the organism entailed at least two concepts to do with change, namely motion (and its laws) and force or energy (and its laws). At times these ideas seemed to merge into one, as when in Chemistry and physics he attacked the explanation of fermentation given by Matthias Schleiden (1804-1881). ${ }^{131}$ The details of Schleiden's explanation need not concern us; suffice it to notice that Liebig attacked him for an incorrect appreciation of motion and forces and their relations. ${ }^{132}$

We can see Liebig's own appreciation of such relations and of their import in the vital economy towards the end of Chemistry and physics where he emphasized the importance of a dynamical type of physiology and the inadequacy of all attempts hitherto made - by both vitalists and reductionists. A consideration of electricity, magnetism, heat, and chemical force led him to conclude

". . . that finally when we see how the causes or forces, from which the properties of bodies and their capacities to make an impression upon our senses stand in a relation of mutual dependence to each other, we cannot doubt that the vital properties are equally dependent with all others upon these laws, and that the chemical and physical properties of the elements, with their form and method of arrangement, play an appreciated and appreciable part amongst the phenomena of life."133

Elsewhere he asserted that physiology, no less than physics, depended upon the conviction that a set of laws existed which concerned relations among causes and between these causes and their phenomena, and that when a clear conception had been obtained of such relations a number of questions thrown up by experimental science might be resolved without the need for further observations. ${ }^{134}$ In other words, he looked towards a sounder theoretical basis for the physical and organic sciences together; and at the heart of that theory lay an understanding of causality and force. However, as in previous writings, the inscrutability of force itself was emphasized. For

130 Ibid., pp. 76-77.

131 M. Schleiden, Gründzüge der Wissenschaftlichen Botanik, Leipzig, W. Engelmann, vol. 1, 1842, vol. 2, 1843. Liebig cited the second edition, 1845-1846. The reason for his citing the second edition, indeed for his singling out Schleiden for attack, was probably because Schleiden had criticized his Agricultural chemistry in a small pamphlet called Herr Dr. Justus Liebig in Giessen und die Pflanzenphysiologie, Leipzig, W. Engelmann, 1842. Schleiden's criticism had been severe and Liebig probably took it as an assault on his scientific competence, which would account for the severity of Liebig's criticism of him in Chemistry and physics.

132 Liebig, op. cit., note 116 above, pp. 82-83.

133 Ibid., pp. 103-104.

134 Ibid., pp. 91-93. 


\section{The role of force or power in Liebig's physiological chemistry}

instance, in a discussion of the causes or the dynamical conditions responsible for the boiling-points of liquids (for which he put forward a tentative law relating boilingpoint to chemical formula), he commented that "the knowledge of this natural law is quite independent of the actual cause, or of the conditions which, taken together, effect the constant boiling-point, for we are as ignorant of what relates to the boiling-point, as we are concerning the conception of life."135

Whilst Liebig was thus joining other physiologists in seeking a new dynamical explanation of life, yet denying any understanding of the nature of force itself, he was also dissatisfied with the direction this search had taken. As usual, he mentioned no names, but it is not unlikely that he had in mind particularly Müller's reductionist students (as well as other critics of vitalism in France and England). His thoughts on this issue resemble closely Müller's and reveal the tensions that he was trying to resolve:

"Another fundamental error entertained by others is, that one may attain to an explanation of vital phenomena by chemical and physical forces alone, or in combination with anatomy; it is, indeed, scarcely to be supposed that the chemist should be able, merely by the knowledge of chemical forces, to explain the existence in the living body of new laws and new causes, or that the physiologist, setting aside the action of chemical or purely physical forces, should endeavour to account for every process by the aid of the laws of inorganic nature.

"The latter view is the ultimate consequence of a reaction from the previously entertained views. In a period of philosophical physiology not very remote from the present day, everything was explained by vital force. This theory was next wholly rejected, and the possibility assumed of our being able to trace all vital processes back to physical and chemical causes. 'In the living body', thus wrote physiologists forty years since, 'there are different laws at work from those which govern inorganic nature. All the processes of the living organism are of a peculiar character.'

"In the present day, many physiologists, on the contrary, regard these various processes as similar in character. The evil of both these theories is that neither then, nor now, has any attempt been made to establish, or even to investigate, the deviations occurring in the effects of vital force and in the action of inorganic force, or to determine their similarity and difference.

"The deductions drawn were not based upon a knowledge of the difference or similarity of their mutual relations, but upon ignorance of these characteristics."136

This passage was followed by an explicit denunciation of those who regarded vital processes as effects of inorganic forces alone. Such philosophers, he declared, entertained an exaggerated idea of chemistry, 137 and they "entirely forgot that the expression chemical force means nothing more than the quantitative character of different vital indications and the qualities dependent upon those quantities." 138

135 Ibid., p. 97

136 Ibid., pp. 107-108.

137 Ibid., p. 109.

138 Ibid., pp. 108-109. 
Indeed, so far from the truth were such philosophers that Liebig felt the maturation of a true dynamical physiology was still far ahead: "The time will come," he wrote in the concluding paragraph of Chemistry and physics, "although perhaps the present generation will barely live to see it, when a numerical expression for chemical formulae shall have been obtained for the measurement of all the normal energies of the organism . . . ."139

\section{CONCLUSION}

In this section I shall attempt to characterize Liebig's physiological dynamics, pointing out those issues over which I agree with other scholars and those over which I disagree. I shall also discuss possible reasons for Liebig's generally ignoring the work of other physiologists in this particular field.

One of the principal thrusts of Liebig's discussions on force and life was to show that his conception of the vital force belonged as legitimately and scientifically to the pantheon of powers and forces as did agents like heat, chemical affinity, electrical and magnetic force. There can be no doubt that he envisaged a tight interdependence among all forces, that despite their essential differences there was an essential equivalence or correlation among them. The absence of any explicit use of the term "correlation" or of any citation of Grove's deliberate and extensive employment of it does not, in my view, cast doubt on Liebig's believing in a correlation of forces or on his desire to make that view as rigorous and as far from the Naturphilosophie-type metaphysics of force as possible. In keeping with this aim towards a rigorous, respectable concept of force, he attempted to quantify the relations between Kräfte. In this attempt in his Animal chemistry he juggled with words and ideas which, without excessive hindsight, we can recognize as having something to do with work and energy. We may go even further and assert that his ideas on the relations or laws of motion, work, and "momentum of force" did possess a kinship with the principle of the Conservation of Energy as it was enunciated in the late 1840s and 1850s. To call Liebig's ideas and the formal principle of energy-conservation identical would be nonsense, of course, for the words that were used by him differed from those used by Helmholtz and Joule and later by William Rankine (1820-1872), Rudolf Clausius (1822-1888), and William Thomson (1824-1907). And words are not merely approximate symbols for certain ideas, for they serve to shape the very ideas they represent. Despite such terminological, and hence ideational, differences and ambiguities I have attempted to offer substantial support for Kuhn's contention that Liebig was one of those who were feeling their way towards a type of energyconservation within the period $c .1825-1850$. Kuhn suggested that by $c .1842$ several lines of enquiry had become so concatenated that the conservation-principle could and should be enunciated. One of those lines was clearly Liebig's brand of chemical, physiological dynamics.

Liebig's attempt, especially in Animal chemistry, to render his ideas on force quantifiable suggests that he was trying to make this issue as scientific and verifiable as possible. On this point I find myself disagreeing with at least one scholar who asserted that Liebig's metabolic theory, particularly his ideas on animal heat and other aspects 139 Ibid., pp. 115-116. 


\section{The role of force or power in Liebig's physiological chemistry}

of force, had a "lack of falsifiable contents." 140 Not only does this seem to me to be inconsistent with the general tenor of Liebig's work, ${ }^{141}$ but the very extensiveness of his discussions on metabolism and dynamics testifies to his concern that his ideas should be displayed in public for the scrutiny and use of physiologists and chemists. We know beyond doubt that Liebig presented his Agricultural chemistry and Animal chemistry as a programme for a new spirit of enquiry; 142 and when that spirit threw up substantial criticism of particular parts of his work he was known to refine, occasionally even to jettison, them - albeit reluctantly. Liebig's ideas were falsifiable. The fact that his ideas on the role of force in physiology were not really challenged or falsified was due, not to their lack of falsifiable contents, but rather to their accordance with the thinking of some of the leading physiologists of the day. That accordance can be seen not only by comparing Liebig's and Müller's physiologies, but also from the comments that Müller's protégés were making about Liebig's work. For instance, the young Helmholtz in 1845 acknowledged Liebig's leading the way in analysing the concept of vital force. This issue, he wrote, "has recently achieved a much more concrete form in Liebig's attempt to derive the physiological facts from known chemical and physical laws. This new form of the question is: can the force and heat generated in the organism be entirely derived from the metabolic process?" 143

In another article that year Helmholtz pinpointed a central concern of Animal chemistry, that it "postulates the theoretical demand that the origin of heat, as a principle, which corresponds to a force-equivalent [Kraft-equivalent], can be derived only from other forces and not out of nothing." 144

Liebig seemed to Helmholtz to be working along the lines of his own rapidly crystallizing reductionism. Other members of the Müller school also regarded him as an ally, even as a mentor, in their reductionistic programme; for instance, DuBois Reymond attacked him only much later for his refusal to go the whole way with them.

The common strands between Liebig's physiology and that of the Müller school indicate that there must have been a substantial cross-fertilization. Yet Liebig acknowledged them so seldom. Why? In my opinion there were two reasons for his parsimony. First, he believed himself to be the originator of the new type of physiological chemistry and dynamics. After all, he was one of the most skilful and

140 Glas, op. cit., note 5 (xi) above, p. 308. Although Glas is right in suggesting that Liebig's ideas on animal heat and metabolism contained certain assumptions that Liebig did not attempt to examine critically, I cannot see how this caused his theory to have a "lack of falsifiable contents". Indeed, Glas's very next sentence and the following few paragraphs indicate precisely how Liebig's theory was confronted with experimental evidence and thus was modified.

141 It has been said that Liebig's importance lay not in constructing theories which turned out to be true, but rather in constructing theories which, though usually wrong, stimulated much further research. These later researches often refuted or modified Liebig's ideas; but had it not been for Liebig (and the falsifiability of his ideas), physiology and biochemistry would not have developed in the way they did. I think this agrees with Holmes' assessment of Liebig; see especially pp. LXXIX-CXVI of his 'Introduction', op. cit., note 5 (iv) above.

142 See especially pp. XXXIV-XXXV of Liebig's Preface to Animal chemistry, op cit., note 21 above.

143 Helmholtz, op. cit., note 42 above, p. 1.

144 H. Helmholtz, 'Bericht über die Theorie der Physiologischen Wärmeerscheinungen für 1845', in Die Fortschritte der Physik in Jahre 1845, Berlin, Physikalische Gesellschaft, 1847, pp. 346-355. Also reprinted in H. Helmholtz, Wissenschaftiiche Abhandlungen, Leipzig, J. A. Barth, 1882, vol. 1, pp. 3-11. This quotation is from p. 4. 


\section{Vance M. D. Hall}

eminent chemists of his day, and as such he was pre-eminently equipped to bring the techniques and insights of inorganic science to bear upon the life-sciences. One has only to read the final page of his preface to Animal chemistry to see that he was the selfappointed saviour of physiology.

Second, there were metaphysical and other traits in the work of Müller and his school with which Liebig did not wish to associate himself. Let us consider Müller. Although Liebig never explicitly mentioned Müller's one-time adherence to Naturphilosophie or the various metaphysical strands that ran throughout his work, there are sufficient comments against Naturphilosophie and the old school of philosophical physiologists throughout his published writings for there to be no doubt that Liebig held Müller's metaphysics against him. It would not have been difficult for Liebig to grasp Müller's metaphysics, for in addition to his widely discursive Human physiology, whose metaphysical contents I alluded to above, Müller had published other treatises in which his metaphysics were conspicuous. This was true of his very first publication, Zur vergleichenden Physiologie des Gesichtsinnes des Menschen und der Thiere ${ }^{145}$ (On the comparative physiology of sight in man and animals) in 1826. It was even truer of his second publication, a small treatise entitled Ueber die phantastichen Gesichtserscheinungen 146 (On fantastical sight-perceptions) which also appeared in 1826. This latter work described a series of difficult experiments he had done on himself, of the type that Goethe ${ }^{147}$ had advocated and even attempted, whose results Müller interpreted within a Naturphilosophische framework. Müller described the aim of his treatise as follows:

"It deals with the sight-faculty with respect to its higher social bearing upon the organs, whose life-form we call psychic, spiritual. For the author, the soul is only one special form of life amongst many, which is amenable to physiological research; he retains the conviction, therefore, that physiological research itself must in the final analysis be psychological. The doctrine of the life of the soul as a particular life-form of the organism is therefore only a part of physiology, in the widest meaning of the word. . . . Should the author explain himself succinctly on this issue, which he sees as a scientific physiological treatment of psychology, he would declare that, though guarding himself well against the suspicion of Spinozism, he has no doubts upon the last three books of the Ethics of Spinoza, which dealt with the violent emotions and whose psychological content can be seen to be separate from his other teachings . . . . [The last three books of the Ethics] provide at least an accurate account of the method and purport of life, which one cannot say for most psychological treatises." 148

145 J. Müller, Zur vergleichenden Physiologie des Gesichtsinnes des Menschen und der Thiere, Leipzig, C. Cnobloch, 1826.

146 Müller, op. cit., note 48 above.

147 At the time of Müller's publication, subjective studies of sense-perception were not uncommon. Although there were several reasons for physiologists being interested in this type of experimentation, one major reason was Goethe's advocacy of it. The same methodology informed Goethe's work on colours and his rejection of Newton's colour-theory. There is a useful discussion of the influence of Goethe's scientific methodology on physiologists who were studying sense-perception, in Kruta, op. cit., note 40 (ii) above. 148 Müller, op. cit., note 48 above, pp. iii-iv. 
Now read the following paragraphs from near the beginning of Animal chemistry:

"The efforts of philosophers, constantly renewed, to penetrate the relations of the soul to animal life, have all along retarded the progress of physiology. In this attempt men left the province of philosophical research for that of fancy; physiologists, carried away by imagination, were far from being acquainted with the laws of purely animal life .... They professed to explain the most obscure psychological phenomena, and yet they were unable to say what fever is . . . .

"What has the soul, what have consciousness and intellect, to do with the development of the human foetus, or the foetus in a fowl's egg? not more, surely, than with the development of the seeds of a plant. Let us first endeavour to refer to their ultimate causes those phenomena of life which are not psychological . . . ."149

It is difficult not to believe that Liebig had Müller in mind when writing this passage. Müller's treatise on perception contained something else which did not appeal to Liebig, namely an adherence to Aristotle. The sub-title of his 1826 book was Eine physiologische Untersuchung, mit einer physiologische Urkunde des Aristotles über den Traum (A physiological enquiry, with a physiological treatise by Aristotle on the dream). Müller regarded Aristotle's tract on dreams to be a truly physiological one and still very useful. ${ }^{150}$ This use of Aristotle remained with Müller for much, perhaps all, of his life. Since this point is pertinent to Liebig's attitude towards Müller, and no historian of science has commented on it, I shall discuss it briefly.

There is an affiliation between a part of Müller's Human physiology and Aristotle's physiology that would not have escaped the notice of a fair number of Müller's readers. It occurs in the sections 'Of the senses' 151 and 'Of the mind' 152 in volume 2 of Müller's treatise. There, Aristotle's treatise on dreams, De somniis, and his tract on the soul, De anima, are cited glowingly. Moreover, not only are Müller's and Aristotle's ideas in general agreement, but the very layout of Müller's discussion parallels Aristotle's. Müller's section 'Of the mind' begins with a survey of earlier authors in the field Anaxagoras, Heraklides, Pythagoras, Plato, the Neo-platonists, the Pantheists, and Bruno. Aristotle surveys his predecessors in greater detail. Then they discuss the hypothesis that "like attracts like", Aristotle citing Plato's use of it in Timaeus"153 and Müller citing Hegel.154 The next topic they both discuss is the homogeneity and distribution of the soul in the living body; again they are in general agreement. In discussing the senses they follow the same order: Aristotle discusses first senseperception in general, then sight, hearing, smell, taste, and touch (all in Book 2 of De anima), and finally mind and motion (in Book 3). Müller parallels him, the general

149 Liebig, op cit., note 21 above, pp. 6-7.

150 Müller, op cit., note 48 above, p. vii. Müller wrote: "The appended Aristotelian treatise on dreams, closely connected with our object, seems generally to be acknowledged as important for many reasons. Even if it contains errors or hypotheses due to its day, the study is still truly physiological and contains, amongst other things, essentially the correct explanation."

151 Müller, op. cit., note 35 above, pp. 1059-1087.

152 Ibid., pp. 1333-1420.

153 Aristotle, De anima, 404b. 8-17.

154 Müller, op. cit., note 35 above, p. 1358. 
discussion and the five senses occupying Book 5 'Of the senses', and mind and motion following immediately in Book 6 'Of the mind'. Even in one or two of their discussions on a particular sense they seem to follow the same train of thought; for instance, both begin the discussion of touch by discussing whether it is confined to particular, very localized parts of the body or is distributed over its entire surface. Aristotle leaves this question unanswered. 155 Müller's discussion of touch begins by seemingly answering Aristotle's problem. Indeed, by reading the De anima and Müller's discussion side by side, one cannot avoid the impression that Müller deliberately modelled his discussion on Aristotle's and had intended, in this section of his Treatise on human physiology, to bring Aristotle up-to-date for the benefit of modern physiologists.

If we turn to Liebig, we can find several explicit comments on the departure of modern science from Aristotle. The following comment occurs in Animal chemistry just after the comment on the soul and psychology quoted above.

"The modern science of physiology has left the track of Aristotle. To the eternal advantage of science, and to the benefit of mankind, it no longer invents a horror vacui, a quinta essentia, in order to furnish credulous hearers with solutions and explanations of phenomena, whose true connexion with others, whose ultimate cause, is still unknown." 156

If Liebig would not cite Müller because of his metaphysics and his adherence to Aristotle, why was he so reluctant to acknowledge the work of Helmholtz and his colleagues who showed no sign of sharing their master's trait? One reason that I have suggested might be that Liebig considered himself to be the real founder of the new physiology. Another reason, which was probably taking effect from $c$. 1845, was Liebig's realization of the totality of their commitment to the reductionist programme, a totality he did not share. One of Müller's pupils, Virchow, was declaring that commitment in public as early as 1845 . On 3 May 1845, in a public lecture 'Über das Bedürfnis und die Richtigkeit einer Medizin vom mechanischen Standpunkte', he declared that "The new medicine has a mechanistic approach, and its aim is the establishment of a physics of the organism. It has shown that life is nothing more than the totality of phenomena according to physical and chemical (namely mechanical) laws. It denies the existence of an independent life-force or healing force." 157

This programme, which echoed the now-famous assertion by Ludwig in 1842 when he acted as the spokesman for the reductionist quadrumvirate, Brücke, DuBois Reymond, Helmholtz, and himself, was always irreconcilable with Liebig's philosophy of the organism. Liebig's vital force, regardless of how well it fitted into his treatment of the inorganic forces, always kept the organism apart from outright reductionistic models. We see this, for instance, in his last major defence of vitalism, in a lecture in 1856 , which was intended as a critique of contemporary materialism. His criticism of reductionists was even more acerbic than usual; he called them "total strangers to all

155 Aristotle, De anima, 422b.18-423a.2.

156 Liebig, op cit., note 21 above, pp. 7-8.

157 This lecture was first published only in 1907: R. Virchow, 'Üher das Bedürfnis und die Richtigkeit einer Medizin vom Mechanischen Standpunkte', Arch. path. Anat. , 1907, 188: 1-21. 


\section{The role of force or power in Liebig's physiological chemistry}

investigations connected with chemical and physical forces, . . . amateurs . . . ignorant and presumptuous dreamers." 158 Only a simplistic acquaintance with inorganic forces had led people to deny an active force in the organism. A profound understanding of Nature's powers would convince anyone that the cause of the forms and compositions of living systems had to differ from other causes.

This survey of Liebig's chemistry of life has, I hope, shown the extent of his dynamical approach as well as its exploratory and at times uncertain character. Indeed, as many passages in Animal chemistry and the lengthy extract from the end of Chemistry and physics in relation to physiology and pathology show, Liebig was conscious of having to steer a middle course between two sorts of dynamical physiology, between the Scylla of vitalism (and of Naturphilosophie) and the Charybdis of outright reductionism. The steering of such a middle course is rarely, if ever, an easy task. It therefore seems to me that the assessment of at least one Liebig scholar, that his assertions about the vital force do not allow of extracting a coherent and unified view, is valid;159 indeed, that assessment is likely to be valid a priori, for I doubt that it is ever possible for a historian of ideas to obtain a coherent view of the thoughts of a historical figure when that figure was as keenly aware of the intricacy of his task as was Liebig.

This lack of coherence in Liebig's writing, compounded by our own distance from him, has made it difficult for historians to unravel his ideas on the interrelation of forces and on the persistence of force or motion or energy or "Kraftequivalent." But this study of Liebig does develop Kuhn's contention that "previously separate problems were gaining multiple interrelationships" from the 1830 s on, that this new feature "proved to be a major requisite for the emergence of energy conservation", 160 and that Liebig was a key cultivator of that fertile bed of confusion out of which the principle of energy-conservation grew.

\section{APPENDIX}

Turning briefly to Dr. Brock's question - Why, if Liebig was so important historically, does he attract so little attention from both the German- and Englishspeaking historical communities? - this paper can suggest a few tentative reasons. First, Liebig's refusal to align himself fully with the reductionistic physiology which was to set the pace in Germany (and elsewhere) must have diminished his reputation among late nineteenth-century and early twentieth-century historians of science. Starting with DuBois-Reymond's criticism both of his vital force and of his arrogance towards critics of vitalism, ${ }^{161}$ Liebig came in for considerable criticism and even ridicule from physiologists for his reactionary tendencies. Hence, we might assume, his nineteenth-century biographers said little or nothing about his vitalism. Jacob Volhard mentioned it scantily, 162 as if it was an embarrassment. In his otherwise valuable

158 Cited in Lipman, op. cit., note 5 (vi) above, p. 183.

159 Ibid.

160 Kuhn, op cit., note 1 above, p. 324.

161 Hall, op. cit., note 5 (vii) above, p. 275 writes that 1)uBois-Reymond "did not hesitate to apply to Liebig [because of the latter's arrogant attitude towards critics of vitalism] the epithet Gottes-Geissel (an opprobrious epithet otherwise reserved for Attila the Hun!)".

162 J. Volhard, Justus von Liebig, Leipzig, Barth, 1909. 
Faraday lecture of 1875, August von Hofmann, once a pupil of his, declared that Liebig had not been a vitalist of any sort. ${ }^{163}$ The biographies by Kohut 164 and Shenstone ${ }^{165}$ mentioned his vitalism but briefly. Only Theodor Bischoff, another pupil, assessed his vitalism accurately. ${ }^{166}$ Clearly, by the end of Liebig's career, vitalism was fast becoming a black mark in a man's career that positivist historians of science would hold against him.

Another reason for the comparative neglect of Liebig by historians must be the patchiness of his achievements. Whilst his work in pure chemistry and his teaching of chemistry retained a solid reputation, his agricultural and physiological chemistry rapidly became so shot-through with amendments and refutations that his reputation was considerably tarnished even in his own life-time. His contemporaries were well aware of the defects in his work. Holmes has put this well; discussing Liebig's standing towards the end of his life, Holmes wrote that despite the fact that the circumstances which helped to make Liebig's ideas so stimulating in the 1840s had disappeared by 1870 , "Liebig seemed to believe in 1870 that he could still provide directing hypotheses about metabolic processes without testing them on living organisms. By then, however, physiologists had established new approaches and new standards, and no longer took seriously the ideas of an old chemist who had never practised experimental physiology."167

Liebig's poverty of practical experience in agriculture and physiology was well known, and it continued to be recalled throughout the nineteenth century. Indeed, it can be argued that the impracticality of some of his advice in agriculture seriously jeopardized the prestige of agricultural chemistry and scientific agriculture in Britain (and probably also in Germany). One has only to examine the Journal of the Royal Agricultural Society of England between c. 1848 and 1900 to realize the disagreements between (a) Liebig and other agricultural chemists and educators; and (b) Liebig and farmers. The following comments come from a paper written by a well-informed and judicious farmer in Bedfordshire in 1896; writing about agricultural "experts" he said that

“. . . When their teaching was put to the test, those who were unfortunate enough to have incurred expense found they were out of pocket by it. Anyone who may have read what was known as "scientific agriculture" half a century ago must have been struck with the number of theories then promulgated which have since been disposed of. When a farmer adopted them in practice he, as a rule, lost money. Liebig, while doing great good in some directions, prepared the way for the ruin of not a few capable farmers by his mineral theory . . . ."168

163 A. W. Hofmann, The Faraday Lecture, 1875: The life-work of Liebig in experimental and philosophic chemistry, London, Macmillan, 1876.

164 A. Kohut, Justus von Liebig, sein Leben und Wirken, Giessen, E. Roth, 1904. This has a useful bibliography.

165 W. A. Shenstone, Justus von Liebig, his life and work, London, Cassell, 1895.

166 Theodor L. W. von Bischoff, Ueber den Einfluss des Freiherrn Justus von Liebig auf die Entwicklung der Physiologie, München, K. B. Akademie, 1874, pp. 76ff.

167 Holmes, op. cit., note 5 (iv) above, p. CXVI.

168 W. J. Malden, 'Recent changes in fa m practices', J. $R$. agric. Soc., 1896, 7 (3rd ser.): 22-39; this extract from p. 22. 


\section{The role of force or power in Liebig's physiological chemistry}

Not only farmers were affected by the defects of his mineral theory of manures. Manufacturers were too: the Muspratt brothers were almost bankrupted in their making of artificial manures according to Liebig's specifications. But the most telling blows against his reputation as an agricultural chemist were delivered by other agricultural chemists - by Jean Baptiste Boussingault (1802-1887) in France, and by John Bennet Lawes (1814-1900) and Joseph Henry Gilbert (1817-1901) in England. By the 1850s these agricultural chemists, whose practical experiences in agriculture far outstripped Liebig's own, were beginning to cast serious doubt on Liebig's competence in the field; and to make matters worse, Liebig apparently responded not with caution and open-mindedness but with hasty and arrogant dogmatism. His reaction was typified by a letter he wrote to Faraday in 1856:

Münich.

27 July, 56.

"My Dear Faraday,

"I beg you to excuse myself for having so longtime delayed to answer your letter of the 1 May for which I beg to accept my best thanks.

"Since last year I find myself engaged in a very stupid controversy with Mr. Lawes of Rothamsted about Scientific principles in Agriculture. Having never read or understood my book he pretended to demonstrate by experiments that the Science of Chemistry could do nothing for practical Agriculture and that the knowledge of the Laws of nature could not be of any use in practical farming! Mr. Lawes is, I believe, a manufacturer of manure and by my disputing his scientific position and showing that his conclusions are erroneous he thinks to lose his customers . . . ."169

This letter exemplifies Liebig's all-too-frequent mode of response to his critics. Hasty judgement, arrogance, misrepresentation of their positions, and reluctance to acknowledge his own mistakes can be found throughout his life's work. Perhaps this did as much to lessen his stature in the eyes of historians as anything else. After all, it is difficult to study a man as a great figure, (which has been the concern of most historians of science until quite recently), if he was seen, not only by his contemporaries to be often wrong, but also by historians to have been querulous and perhaps dishonest in the face of honest criticism. It is at least arguable that Liebig's most telling opponent, so far as his historical reputation has been concerned, was his own character.

169 Letter from Liebig to Faraday, in L. P. Williams The selccted correspondence of Michacl Faraday, Cambridge University Press, 1971, vol. 2, pp. 844-845. 